\title{
GEOLOGY OF CERRO GORDO COUNTY
}

BY

SAMUEL CALVIN. 



\title{
GEOLOGY OF CERRO GORDO COUNTY.
}

\author{
BY SAMUEL CALVIN.
}

\section{CONTENTS.}

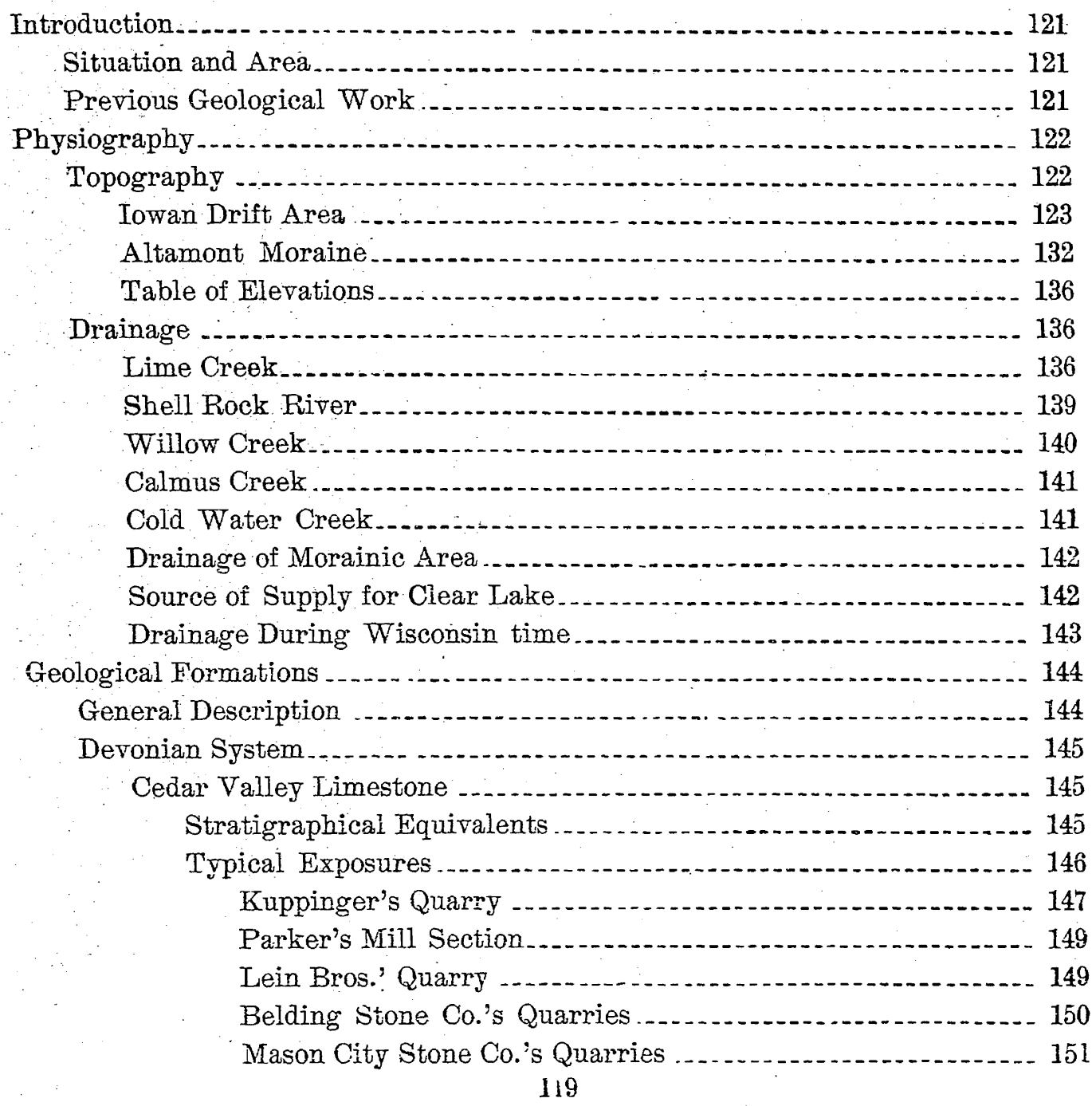




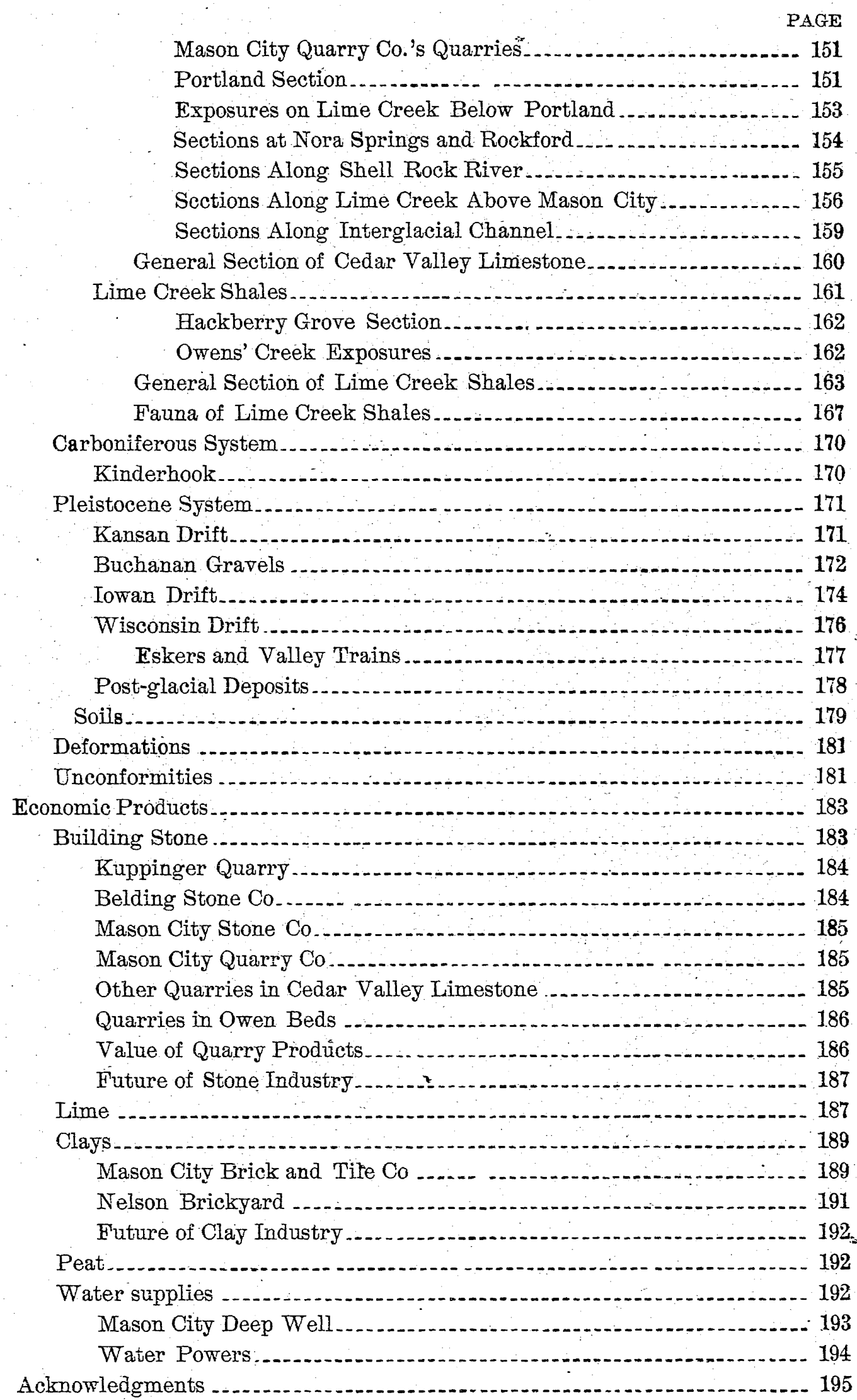




\title{
INTRODUCTION.
}

\author{
SITUATION AND AREA.
}

From an agricultural point of view Cerro Gordo county embraces one of the most beautiful tracts of land in Iowa. The region indeed is not without the charm of beauty from any point of view. This county lies well toward the west line of the northeastern quarter of the state. It is only seventeen or eighteen miles from the Minnesota boundary. Worth county, on the north, separates it from Minnesota. It has Hancock county on the west, Franklin on the south, and Floyd on the east. It is approximately square, embracing the usual sixteen congressional townships. Outside of Mason City each congressional township is:now organized into a civil township.

\section{PREVIOUS GEOLOGICAL WOPK.}

Cerro Gordo county has received but little attention in previous official surveys. It was not included in the area directly investigated by Owen, nor does the report of Prof. James Hall refer to it in any way. The survey conducted by Dr. Charles A. White covered some of the more prominent characteristics of the region, and his report* devotes a few pages to the description of Cerro Gordo and Worth counties considered as a single area. There are also, in the same report, some references to the peat of Cerro Gordo county in the - chapter on Economic Geology, and to certain topographic phenomena around Clear Lake, under the head of Physical Geography. In 1872 there was published, as advance sheets of the Twenty-third Annual Report on the State Cabinet of New York, a paper by Hall and Whitfield, in which some fossils from the shales at Hackberry Grove are described and the geological age of the formation is discussed.

In the Ninth Annual Report of the Geological Survey of Minnesota, Mr. Warren Uphamt discusses the terminal

* Report on the Geol. Surv. of the State of Iowa, Charles A. White, vol. II, pp. 249-253, Des Moines. 1870 .

+ Geol. and Nat. Hist. Surv, of Minn. Ninth Ann. Rep; pp. 298-299. Minneapolis, 1881.

11 G. Rep. 
moraine of what is now known as the Wisconsin drift sheet, and gives some details respecting its course and characteristics in Cerro Gordo county. MeGee has a brief description of the dolomitic building stones at Mason City in the report on the tenth census; $*$ and the same authort discusses the characteristics of the Lime Creek shales at Hackberry Grove in his monograph on the Pleistocene History of Northeastern Iowa. The Hackberry Grove fossils have also been the subject of papers by Williams, Calvin and Webster.

\section{PHYSIOGRAPHY.}

\section{TOPOGRAPHY.}

The topography of the greater part of Cerro Gordo county might be regarded by some observers as somewhat characterless and monotonous. Leaving out the western tier of townships the remaining portion of the county is a gently undulating drift plain, almost level over large areas. Stream valleys that have cut to but a very limited extent below the general level, and a few knobs or ridges that rise to a height of twenty to thirty feet above the otherwise unbroken plain, give some diversity to a landscape in general devoid of salient topographic features. The drift covering the county is in some places very thin; erosion since the deposition of the drift has been insignificant in amount, and hence the most conspicuous hills and valleys of eastern Cerro Gordo are in reality remnants of a preglacial topography.

All the eastern part of the county is occupied by Iowan drift; the western tier of townships is almost wholly occupied by the knobs, ridges and kettle holes that characterize the marginal moraine of the Wisconsin drift, the Altamont moraine of Chamberlin. A small area in the southwest corner of Grimes township presents some of the characteristics of plains of Wisconsin drift; but this last area is so small as to make it comparatively unimportant. The county is, therefore,

* Rept. Tenth Census, vol. X, pp., 261-263.

tEleventh Añn. Rept. U. S. Geol. Surv., p. 314. 
topographically divisible into two principal areas, the area of the Iowan drift and the area of the Altamont moraine.

AREA OF IOWAN DRIFT.

The Iowan drift area, which occupies about three-fourths of the surface of the county is, as already stated, a plain, only slightly modified by surface irregularities. The most marked topographic features of this area are associated with the valley of Lime creek. From the point at which the stream enters the area of Iowan drift, near the northwest corner of Lincoln township, until it leaves the county near the southeast corner of Portland, Lime creek flows in a wide and ancient valley that has been only partly filled with debris by the several glaciers that have successively occupied the region. The valleyvaries in width from one-fourth of a mile to more than three miles. In depth it ranges from from twenty to seventy feet. The channel that has been cut since the deposition of the Iowan drift is a shallow trough wide enough to accommodate the stream in ordinary stages of water. There is, strictly speaking, no flood plain, at least there are no alluvial deposits; but a plain covered with Iowan drift and strewn with conspicuous Iowan bowlders, usually begins at the margin of the shallow channel, and is doubtless partly overflowed at high water. In the western part of Lime creek township the stream flows nearly east from the west line of the township to near the center of section 27. In this part of its course the valley is bounded on the south side by a steep escarpment, twenty to thirty feet in height, in places rocky, in other places seemingly made up of drift. The stream flows close to the foot of the escarpment. A low drift covered plain begins near the level of the water on the north side of the channel and extends back from one-eighth to more than one-half mile. The plain rises gradually to the north and is bounded in this direction by a more or less defined terrace eight or ten feet in height. From the margin of the terrace a second plain, which, like the first, is gently inclined toward the stream, reaches north- 
ward with a maximum width of two or three miles, and terminates in low, imperfectly defined hills. These low hills mark the margin of the old preglacial valley, and beyond them stretches away the unbroken drift plain.

Southeast of Mason City the creek flows near the middle of its old valley, and the escarpment forming the eastern boundary cuts obliquely the west line of section 7 of Portland township. The height of the escarpment above the second bench of the river valley is, at this point, thirty-five feet. The boundary of the valley is similarly marked on the west side at a distance of a mile, or a mile and a half from the stream.

In the southern part of Portland township, the Lime creek valley trends nearly east. Here again the stream flows near the southern margin of the valley. For some distance it follows the foot of an escarpment made up of Lime creek shales and presenting a front seventy feet in height. From the summit of this escarpment the normal drift plain stretehes away with gentle undulations to the south. On the north side of the stream the bowlder strewn plain begins near the level of the water and rises very gradually toward the north until, at a distance of two or three miles, without marked break or change of slope, it blends into the plain of drift which lies at the general level of all the eastern part of the county. In the immediate neighborhood of the stream, however, there is the unusual spectacle of two drift plains of the same age, sharply offset one from the other by a vertical rise of seventy feet. The interesting relations of thèse two plains are due to topographic features imposed upon the region before the oncoming of the earliest glacial period. The offset between the two plains is most marked where the stream flows close to the foot of the escarpment in sections 34 and 35 , but it is continued westward through sections 33 and 32 , receding farther and farther from the stream, and is finally lost in the general level of the county at the western limit of the preglacial valley. 
The valley of Lime creek abounds in interesting features throughout its whole course in the county. In the Iowan drift area it had been excavated to a great width in preglacial time and probably accommodated one of the master streams of ancient Iowa. The valley was partly filled with Kansan, and probably with an earlier drift, but during the interval following the Kansan ice invasion, it was in part re-excavated,- the terrace already noted in Lime creek township, and similar terraces at other points along the valley, indicating the width attained at the time the interval was brought to a close by the invasion of Iowan ice. This later ice distributed only a thin mantle of drift which failed to disguise the pre-existing topography. A thin sheet of till, with numerous and large bowlders was spread over the higher plain, over the terrace, or second bench, and over the low plain

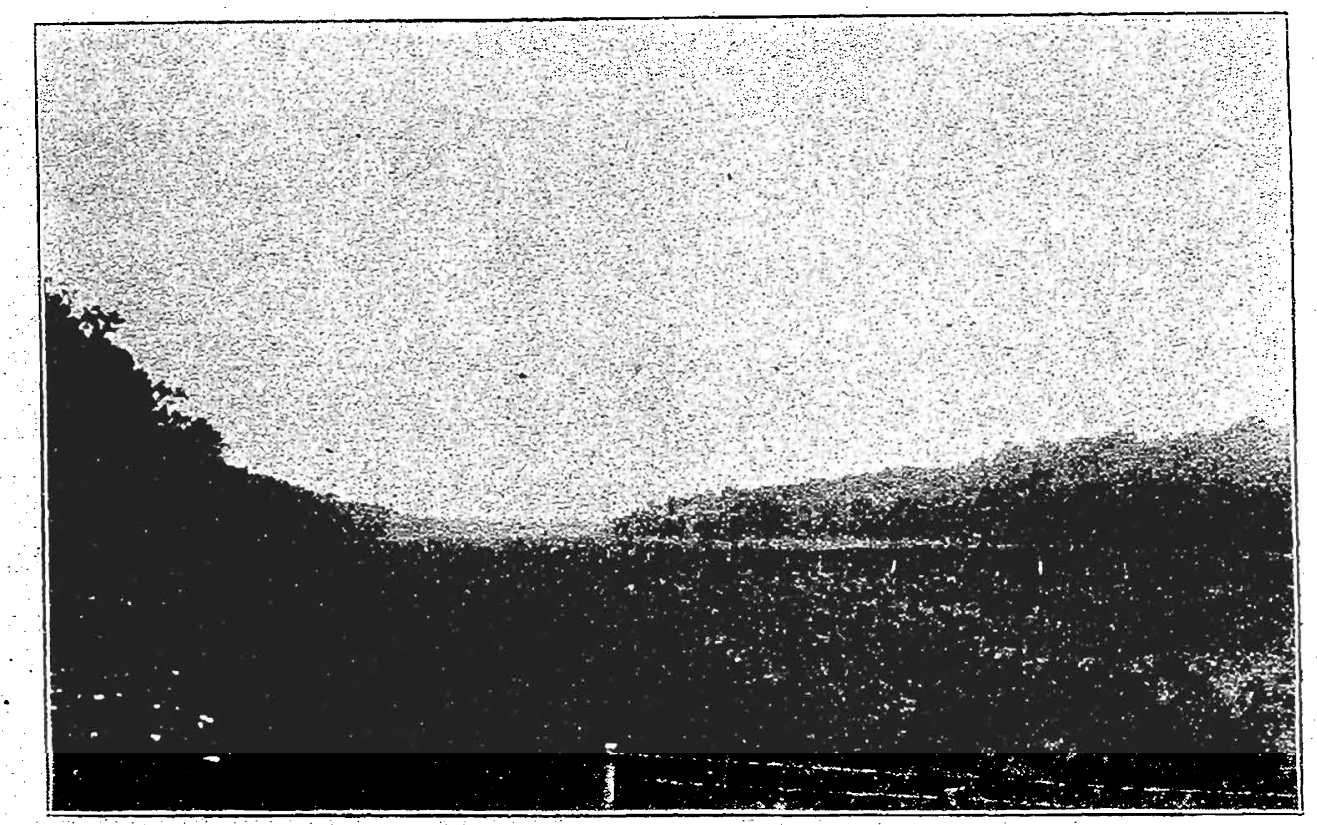

FIG. 11. Abandoned channel of Lime creek north of Mason City. This is an interglacial channel, apparently excavated and occupied by the stream during the interval between the Kansan and lowan stages of the Pleistocene. This interval includes three distinct episodes, namely: the Buchanan interglacial stage, the stage of the invasion of sc utheastern Iowa by the Illinois ice sheet, and the interglacial stage (unnamed) following the retreat of the Illinois ice.

formed by the excavation of the valley during the long interglacial interval following the withdrawal of the Kansan ice. The present shallow and comparatively narrow channel repre- 
sents the amount of erosion since the close of the Iowan glacial period.

An abandoned channel of Lime creek, with well defined rocky bluffs that are in places forty feet in height, (Fig. 11) is an interesting topographic feature in sections 27,34 and 35 of Lime creek township, and section 2 of Mason City. At the elbow of the stream east of the center of section 27 in the first named township, the present channel bends toward the southwest, while the abandoned channel trends almost directly south. The southerly course is maintained for a little more than a mile, when the channel bears southeast and crosses the south line of the township from sixty to eighty rods east of the southwest corner of section 35. In section 2 of Mason City township it maintains its southeasterly direction, but in the northeast quarter of this section it enters an expansion of the old preglacial valley and loses its character as a definitely bordered channel. The course of the stream that excavated this old channel continued southeastward beyond the middle of section 1, and then turned southward to join the present channel near the south line of section 12, Mason City township. The part of the channel of greatest interest is that in sections 27,34 and 35 of Lime creek, and the northwest quarter of section 2 of Mason City. It is in this part of its course that it is defined by rocky bluffs. Here it is also narrow, scarcely exceeding 100 yards in width. Topographically the channel is young. It was occupied for only a very short time as compared with the geologic ages required to excavate the. broad valley which the stream generally follows in the Iowan drift area in other parts of the county. As to the age of the narrow rock-walled portion of the channel there is evidence that the excavation was completed before the invasion of Iowan ice, for Iowan drift and numerous typical Iowan bowl-: ders lie apparently undisturbed throughout the greater part of its course. The present stream seems to follow the preglacial valley, so that it is scarcely possible that this channel was cut and afterward abandoned in preglacial times. The 
most probable succession of events would be, (1) a preglacial valley occupied by an important stream was cut to a width of from two to three miles. In places the width may have exceeded the maximum given; in others the real width may have been less than the minimum. One of the narrower parts of the old valley was just below the point at which the abandoned channel diverges from the present one. (2) The narrow part of the preglacial valley was choked with dirt during the advance and retreat of the Kansan ice. (3) After the disappearance of the Kansan ice the drainage in general followed the old valley, but owing to obstructions, probably not far below the point at which the divergence occurred, the stream was turned aside and compelled for a short distance to make a new channel in which it continued to flow during the interval between the Kansan and Iowan drift periods. The channel cut during this interval is in reality only about two miles in length. In the remaining portion of its course until it joined the present channel, the stream followed the eastern portion of the preglacial valley. (4) During the Iowan glacial period two things probably occurred. The obstruction of Kansan drift may have been in part plowed away, and the channel followed by the stream during the interglacial period may have been in part filled with Iowan drift. That the now abandoned channel was so filled in part is attested by observed facts; and whether the obstruction in the preglacial valley was plowed out or not, the stream, after the retreat of the Iowan ice, left the channel it had made in interglacial time, and once more followed the older valley. On this hypothesis the abandoned channel represents the amount of rock cutting accomplished in the interval between the Kansan and Iowan glacial stages. Compared with the amount of erosion since the close of the Iowan stage it is many times as great. It may safely be asserted that the interglacial period in question was relatively long. A comparison of Figures 11 and 12 may afford some measure of the relative length of the two intervals. Figure 11, however, 
shows only a part of the rock cutting accomplished in the period between the Kansan and Iowan stages, for the abandoned valley is now filled to a depth of several feet with drift and peaty humus, while Figure 12 shows the entire amount of valley-making accomplished by the Shell Rock river at the point chosen for illustration, in all post-Iowan time.

The northeastern corner of the county is traversed by the valley of Shell Rock river, a valley very different so far as relates to its history and topographic characteristics from that of Lime creek. Shell Rock valley is new. It traverses the higher drift plateau. Its depth as a rule is only a few feet below the general drift plain and its width is just suff-

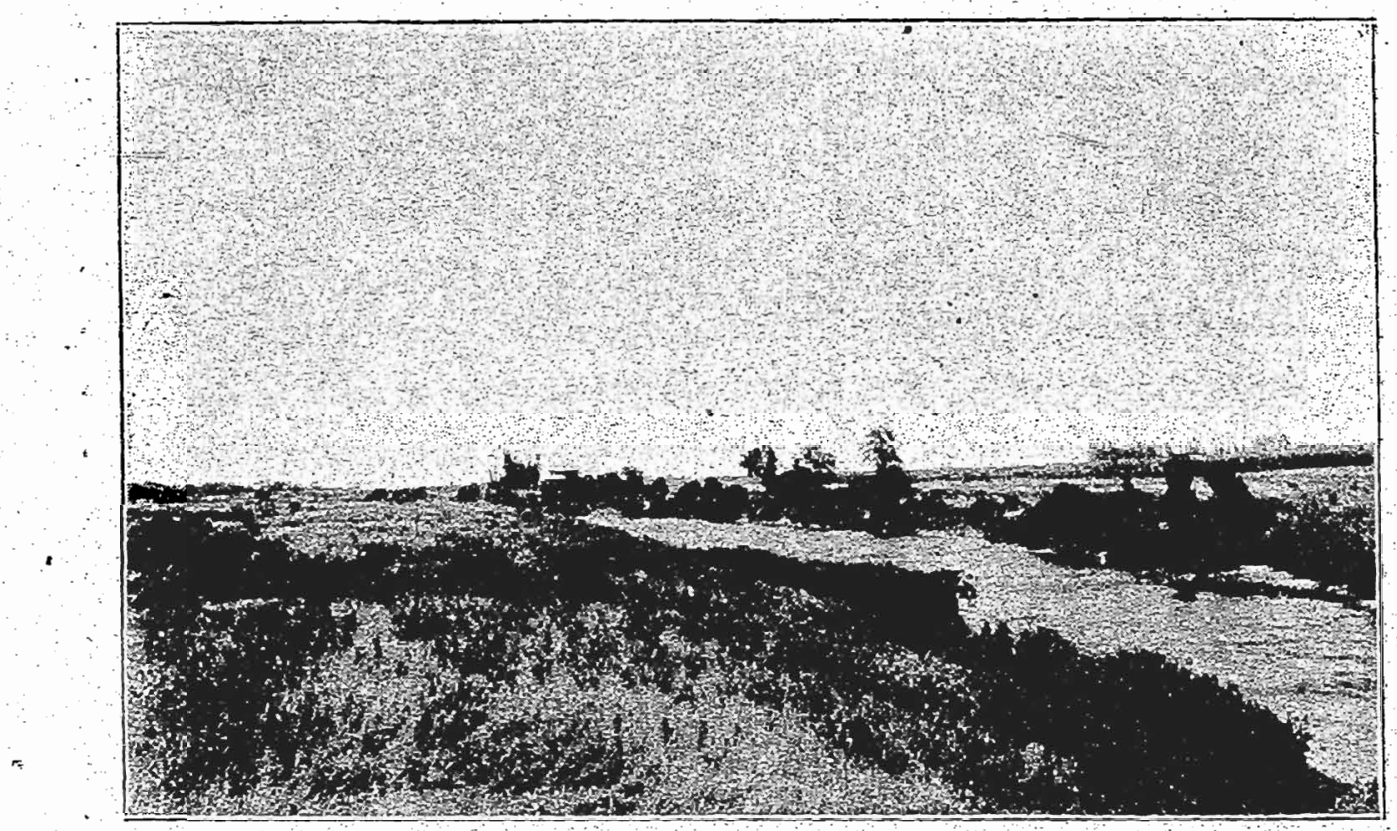

FIG. 12. View on the Shell Rock, showing the very shallow trough-like channel cut in the Iowan drift and underlying limestones. The contiguous fields are cultivated practically to the water's edge. Northwest quarter of sction $2 \pi$. Falls township.

cient to accommodate the present stream. In many places the drift plain, with its houses, barns and cultivated fields, begins at the margin of the shallow, trough-like channel and spreads away without perceptible slope, to the horizon (Fig." 12). In other places the stream has cut through low ridges of rock and developed miniature bluffs that persist for a short dis: tance and then fade into the low grassy slopes that come down 


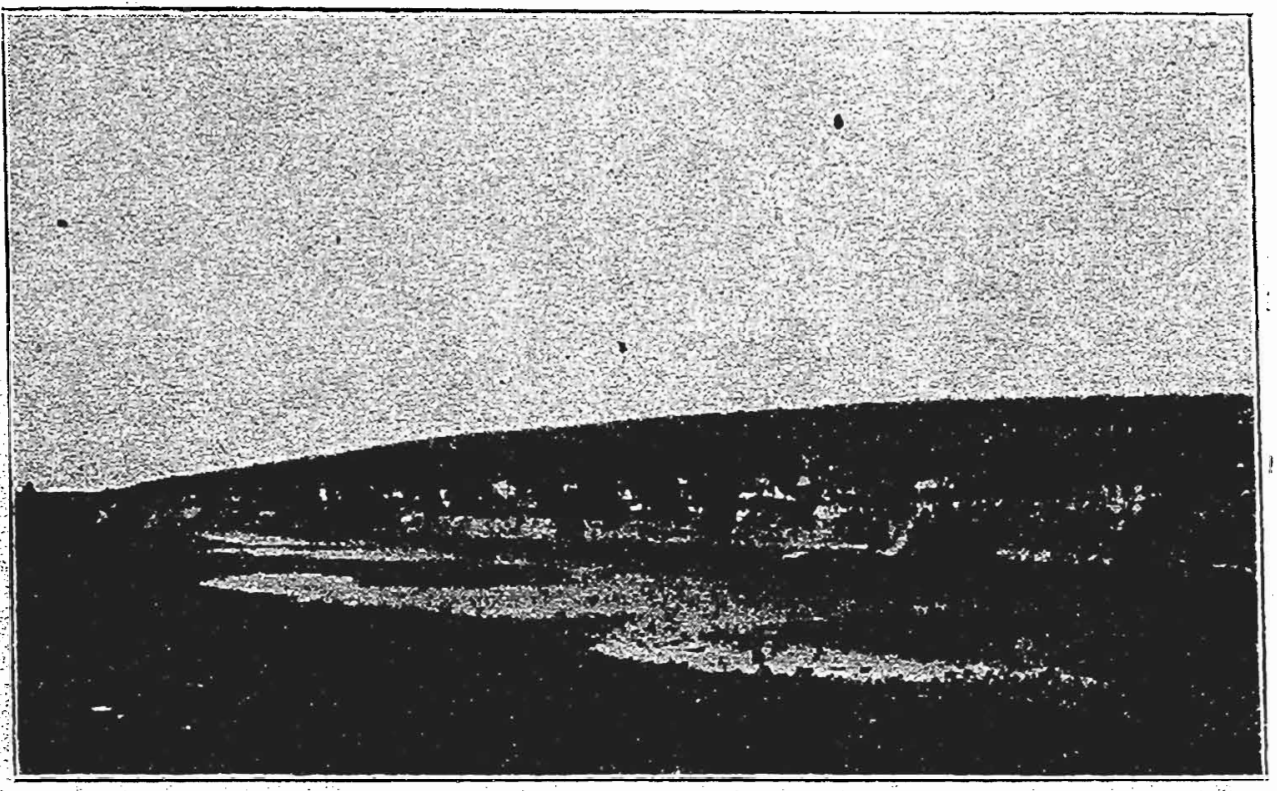

Fra. 13. View of the low rocky bluff on Sheil Rock rlver, in northwest quarter of section 26. Falls town: h'p.

to the water's edge (Fig. 13). Below Plymouth for a few miles the channel is cut continuously in rocky strata to a depth of eight or tên feet. At a few points, as at Vermilya's bluff in Sw. qr., Ne. $\frac{1}{4}$, Sec. 35, Falls township, the rocky walls on oneor the other side of the valley attain a height of thirty or

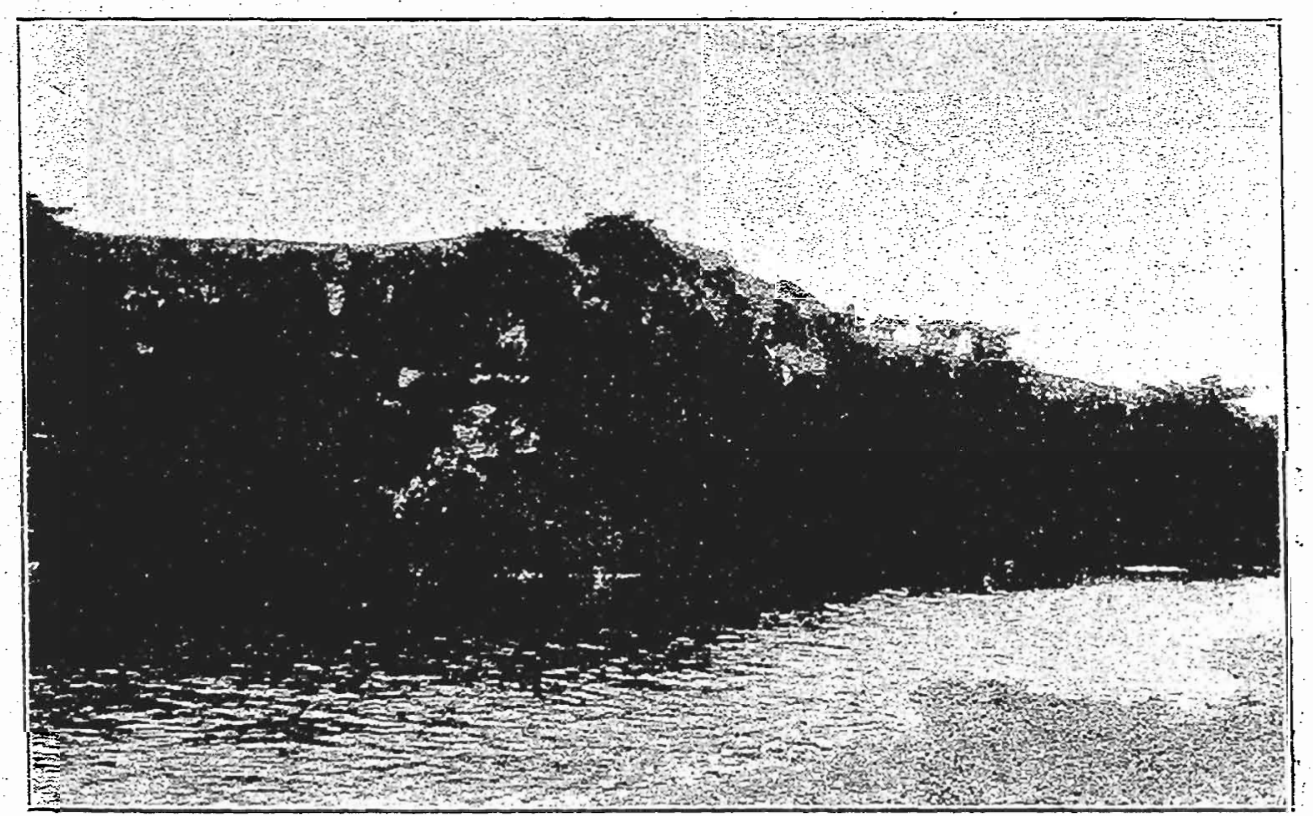

FIG. 14. Vermilya's bluff, the highest rbcky escarpment on the Shell Rock river, in Cerro Gordo county. Northeast quarter of sectron 35 . Falls township. 
forty feet (Fig. 14), but in such cases the bolder topography is due to conditions developed in preglacial time. In general the valley of the Shell Rock in Cerro Gordo county is narrow and shallow, and represents work accomplished by the stream since the retreat of the Iowan ice.

In the vicinity of Mason City the valley of Willow creek shows the same characteristics as the valley of Lime creek. It has a depth of fifty feet measured from the level of the water in the stream to the summit of the hill west of the C., M. \& St. P. depot. A short distance west of the depot the

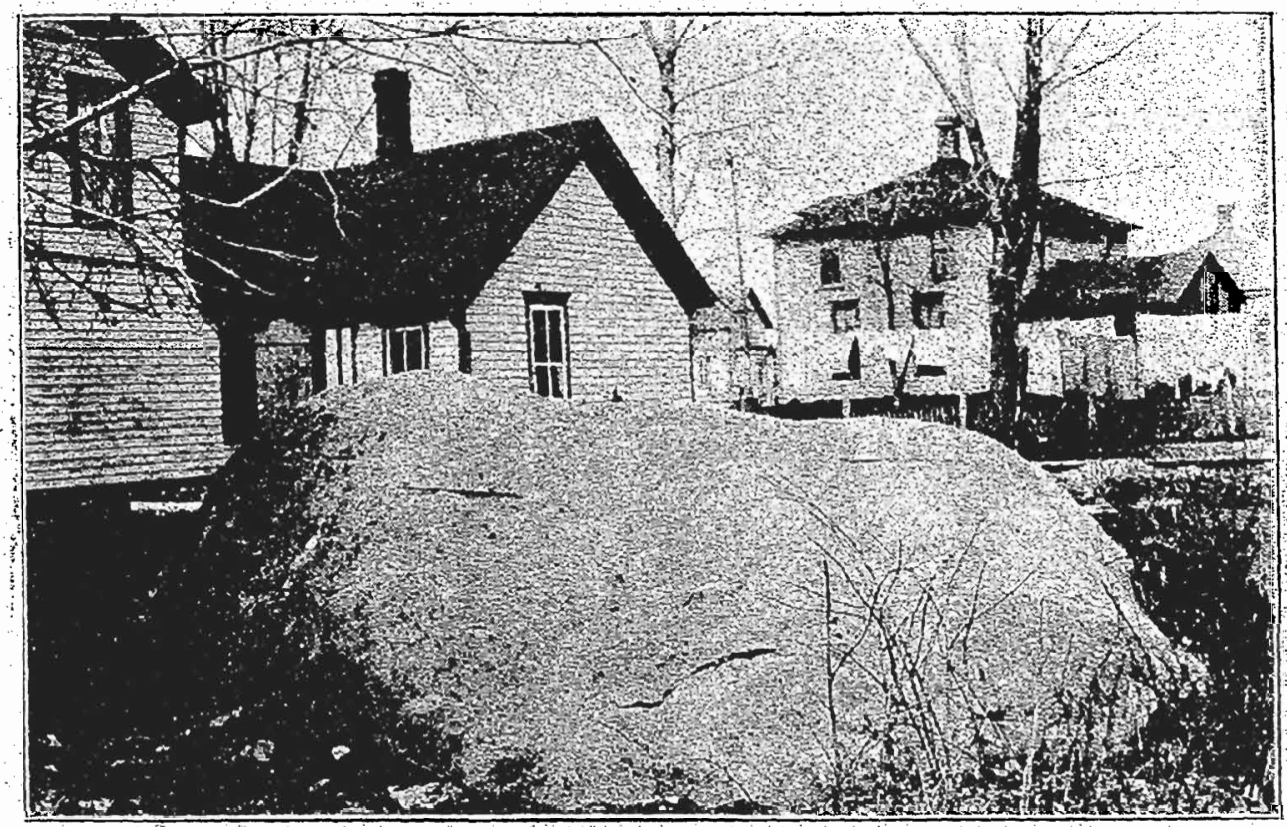

Fig. 15. Iowa bowlder in Mason City, on low plain within the walls of the preglacial valiey of Willow creek.

railway cuts through fossiliferous beds of the Lime creek shales, but the bottom land between the railway and the stream, averaging half a mile in width, is covered with drift to a depth in places of fifteen or twenty feet. A valley more than fifty feet in depth; and fully amile in width was excavated here before any drift was deposited. Iowan bowlders, some of them of great size (Fig. 15), lie scattered over the low plain within the walls of the valley as over the corresponding plain along Lime creek. Here as in many other parts of the county 
the successive drift mantles were in the aggregate too thin to completely obliterate the preglacial topography. The valley was never more than partially filled with drift, and beyond the limits of the valley, on the plain south of the railroad, the plain in which the valley was cut, the dritt mantle is so thin that Lime creek shales of Devonian age are exposed by the plow.

Preglacial hills and ridges stand, out to a limited height above the general surface in sections 16 and 17 of Lake township. In the northeast quarter of 17 there is a low ridge, half a mile in length, trending northwest-southeast, and composed of Lime creek shales with scarcely any covering of drift. This ridge lies between the forks of Willow creek. Its structure, and its relations to the drift lying in the adjacent valleys and lapping up on its sides, indicate that it belongs to a system of topography developed before the earliest glacial period. A similar ridge, with drift bowlders sprinkled over its surface, but with a soil made up of decomposed Devonian shales, extends through the northern part of section 16.

A ridge, conspicuous for this region, passes from section 24 of Mason township into section 19 of Portland. It rises sixty feet above the valley of Lime creek, and twenty feet above the drift plain to which the road descends from its summit toward the south. Near the summit the rain-wash in the sides of the road expose undisturbed shales of the Lime creek stage. A thin sheet of till extends over the ridge, and heavier bodies lie on the lower grounds on either side; but the body of the ridge itself, as an eminence overlooking low lands on the north and south, is older than the oldest drift.

The scantiness of the drift materials in certain localities, and the fact that the present hills and valleys are, to a large extent, remnants of a preglacial topography, are well illustrated at numerous other points within the county. For example, there are many bowlders lying over the plain that begins at the summit of the seventy-foot escarpment in section 
35 of Portland township, but in cultivating the fields the farmer drives his plow through Devonian shales. The same shales are cut through by the roadway at the summit of a long hill near the southeast corner of section 24 in Owen township, while undisturbed drift lies deeply over the adjacent valleys. Along the road leading from Mason City to Clear Lake, almost every excavation, whether made in hill or valley, cuts through the thin layer of drift and reveals the yellow shales, which here constitute the country rock. In the southwest corner of Portland township there are numerous exposures illustrating the same relations. The valleys contain undisturbed drift and the hills are made up of undisturbed country rock.

Over large areas in the eastern part of Cerro Gordo county the drift is, after all, comparatively deep, and outside of such phenomena as have been discussed above, this area may be looked upon as a drift-plain with gentle undulations that are not always erosional in origin. A typical portion of this plain begins at the eastern or northeastern margin of the old Lime creek valley and occupies nearly all of Falls township, together with adjacent parts of Lime Creek and Portland. The same plain, broken only by the post-glacial erosion of a few small streams, covers nearly the whole of the area east. of the Altamont moraine and south of the valleys of Willow creek and lime creek. Throughout a belt several miles in width, and lying on both sides of the northern boundary of Dougherty, Geneseo and Pleasant Valley townships, the plain is typically developed. Its western limit coincides very nearly with the east line of Grimes and Union. An area of similar topography lies between Lime creek and Willow creek in southwestern Lincoln and the northern part of Lake.

ALTAMONT MORAINE.

The area of the Altamont moraine is one of unique topography. Geographically it corresponds very nearly with the western tier of townships so far as it is included in Cerro 
Gordo county. In the southwest it extends a short distance east of the limit of these, and occupies a few square miles in the western edge of Mount Vernon and Pleasant Valley townships. The surface of the area is quite irregular, and presents a series of knob-like hills and undrained marshes arranged in the most lawless manner. Erosion has played a very unimportant part in producing the present surface configuration of this morainic belt.

One of the most broken and hilly portions of the moraine in Cerro Gordo county occurs in the northwest corner of Grant township. The hills are simply knobs of drift that were. irregularly heaped up along the margin of the Wisconsin ice. Their height above the tortuous, marshy valleys that wind in and out and branch and rebranch without definable system, so

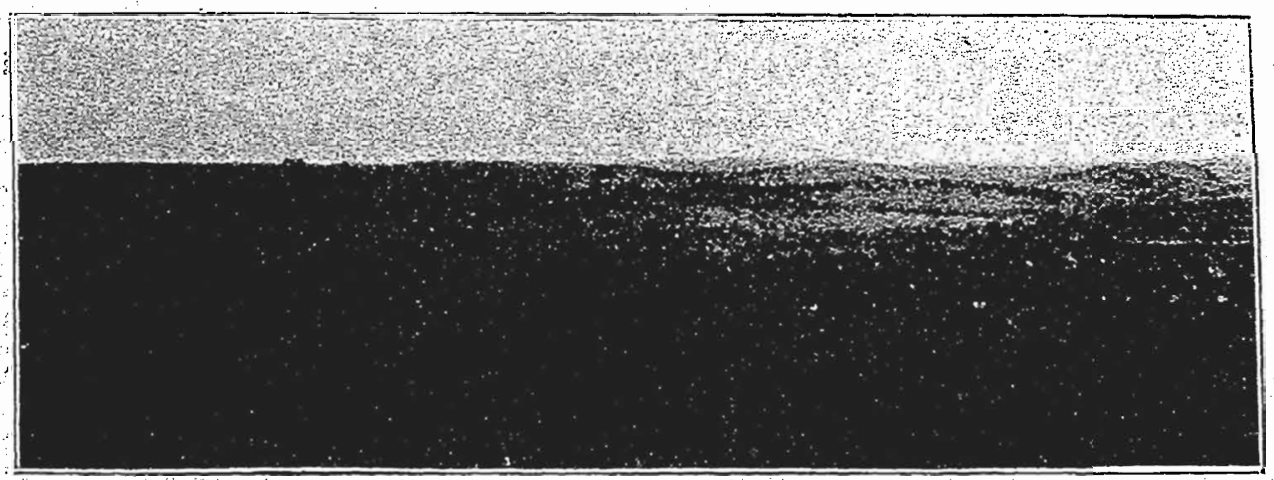

FIG: 16. The Altamont moraine in section 1 of Grant township.

as practically to surround each individual knob, varies from forty to seventy or eighty feet. The slopes are often steep. The traveler following the wagon roads must be content to make slow progress, and must often make long detours to avoid impassable marshes or impracticable bills.

Southeast of Lime creek in Grant township, the irregularities of the surface are less pronounced. The relief is less, the curves are not so sharp, and yet the topography is in marked contrast with the gently undulating plain of Iowan drift that begins not far to the east. The milder features of the knobby moraine are continued southward to Clear Lake, 
and for a few miles south of that body of water the gentler curves that begin south of Lime creek characterize the topographic forms. Section 3 of Grimes township, is the center of an area of considerable extent, in which moranic topography is typically developed (Fig. 16), the moraine here having a width of six or seven miles. In the southern part of Grimes township the knob-like hills are replaced by comparatively gentle undulations.

Kettle holes are very characteristic features of the area. occupied by the moraine: These are saucer-shaped ponds or marshes that, in the majority of cases, are only a few rods in diameter. They are abruptly depressed below the surrounding level, but they may be found in all situations from the low, ill-drained ground between the hills, to the top of the highest eminences. In seasons of ordinary rainfall they are filled with water and may support a dense growth of rushes, wild rice, and less conspicuous aquatic plants. Evidently these peculiar ponds were formerly more numerous than at present, for in many instances peat bogs have taken the place of kettle holes, the depressions having been gradually filled with partially decayed vegetation. Ail these ponds, indeed, are in process of filling, and the cultivation of the hills, which is every year becoming more general, will hereafter result in the mingling of considerable quantities of earthy matter with the peaty deposit.

The basin of Clear Lake is simply a large depression in the: Altamont moraine, and it may be regarded as genetically related to the kettle holes already described. The maximum. depth of the water in the lake is about fifteen feet. Except at the outlet, at the east end of the lake, the basin is surrounded by low knobs and hills of drift.

Lake basins of smaller size than Clear Lake, now generally filled with peat and supporting annually a heavy crop of coarse slough grass, are found at various points within the limits of the moraine. A typical extinct lake bed of the kind described is seen in sections 24 of Union township and 19 of: Mount Vernon. 
At various points along the east end of Clear Lake, as, for example, between the lake and the Assembly grounds, there is a rather low but conspicuous ridge of sand and gravel that is more recent in age than the moraine. This ridge has had the same origin as the "walls" and causeways that commonly occur on the low or swampy sides of northern lakes, and has been produced by the heaving and expansion of the ice during the successive winters that have come and gone since the lake came into existence. The expanding ice is crowded shoreward along that margin of the lake that offers least resistance, and carries with it the clay, sand, gravel, bowl-.

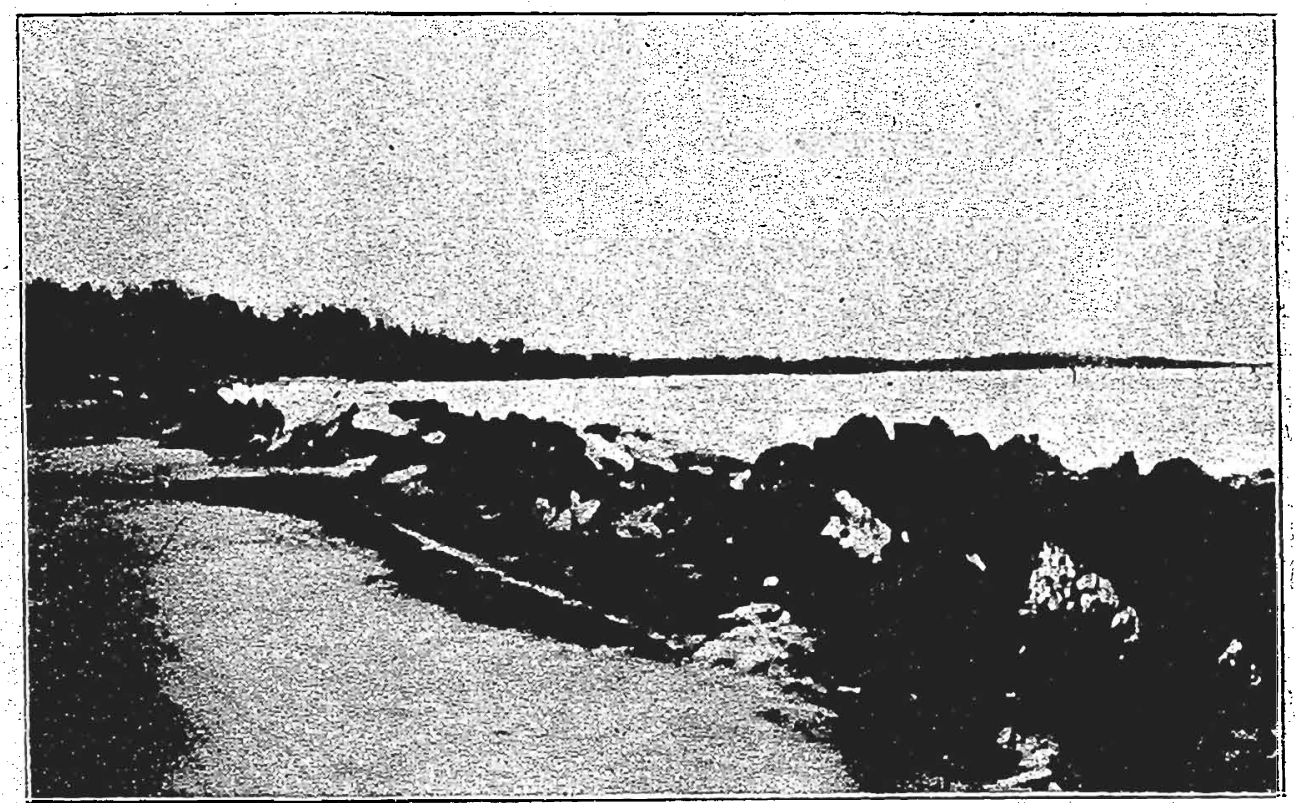

FIG. 17 Effect ne expansion of ice in Cledr Laka. Along the low, gently sloping margins of the lake the ice is heaved and broken and shoved shoreward with tremendous energy, carrying with it great quantities of sand, claj, bowlders and other included materials.

ders or other substances that may be frozen in its lower surface, or are so situated as to be moved by the great mechanical energy exerted in connection with the process of expansion (Fig. 17).

In the western and southwestern part of Grimes township the moranic topography gradually disappears, and the softened curves blend eventually into the level plain characteristic of the area covered with Wisconsin drift. 
ELEVATIONS.

The following table, taken from Gannett's Dictionary of Elevations, shows the relative altitudes of a few of the more important points in the county. It will be observed that the greatest elevations occur at Clear Lake and Ventura, in the Altamont moraine.

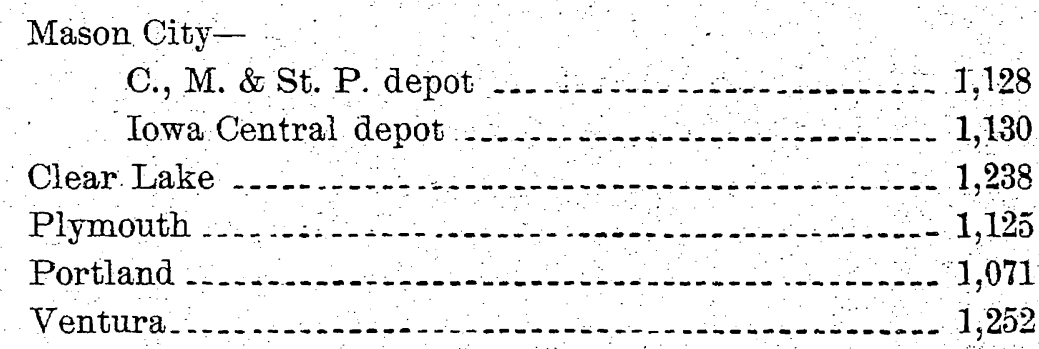

DRAINAGE.

With respect to drainage, as in the case of topography, - Cerro Gordo county is divisible into two areas. The portion of the county occupied by Iowan drift has relatively perfect drainage, and the stream channels are fairly well defined. With the exception of that part of the channel of Lime creek which passes through the northwest corner of Grant township, it can scarcely be said that there is a well defined water course in the area of the Altamont moraine.

Lime creek,-Lime creek drains the larger part of Cerro Gordo county. It enters the county from the southwest, and in the first part of its course it traverses the morainic belt already described. Its course in the moraine is somewhat anomalous. Entering Grant township in section 19 the stream flows northeast and passes into Worth county. Soon after entering Worth its direction is changed toward the east, and after flowing eastward for a few miles it escapes from the moraine and enters upon the area of Iowan drift. Here its course becomes normal for streams in this part of Iowa. It flows southeast, and soon re-enters Cerro Gordo county, crossing the north line of section 5 of Lincoln township. From this point its course is in the main southeast until it leaves the county at the east line of section 36 of Portland township. 
Within the moranic belt, in Grant township, the course of Lime creek is very tortuous, since of necessity it winds back and forth to avoid the lawlessly disposed knobs and hills of drift. In this region the channel is new, dating only from the retreat of the Wisconsin ice. It is now a mere shallow trough in loose glacial detritus, showing only an inconsiderable amount of erosion since the stream began work upon it. There is here properly no river valley, nor are there any tributary streams with definitely marked channels. The drainage waters from adjacent lands find their way into Lime creek, sometimes by very roundabout courses, along broad, flat-bottomed swales, or through reedy, ill drained marshes.

In the Iowan drift area, however, Lime creek follows a preglacial valley that was originally in places two or three miles

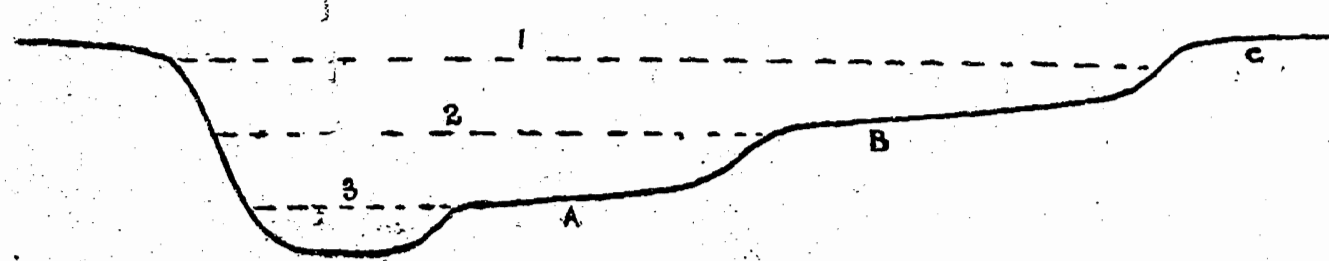

FIG. 18. Profile across valley of Lime creek in western part of Lime Creek township. 1. Width of preglacial valley. 2. Width of valley at close of interglacial stage preceding the advent of the [ow an glaciers. 3. Wfdth of present channel. This channel is a narrow and shallow trough cut in Iowan drift. A. Lower plain, only a fer feet above level of water in creek. This plain is covered with a thin sheet of Iowan drift and is strewn with large Iowan bow Iders that have not been disturbed since they were deposited at the level at which they now lie. B. Terrace into which the interglaclal stream cut the valley No.2. This terrace is underlain by gravel of the age of the Buchanan gravels. It is superficially covered with Iowan drift, and is in places thlckly strewn with Iowan bowlders. C. Highlands beginning at the northern margin of the preglacial valley, covered
with thin mantle of Iowan drift.

in width. In depth the valley varies from twenty to seventy feet. Its history is well recorded in the western part of Lime Creek township. Here the present stream flows in a small, shallow and narrow channel near the southern margin of the valley. The south bank of the stream rises abruptly to a height of thirty or forty feet. On the north side a plain with gentle slope begins near the level of the water and extends back to a terrace that is eight or ten feet in height. At the summit of the terrace there begins another plain that may be two miles or more in width, and is terminated on the north by an irregular line of low hills. The history seems to have been as follows: The preglacial valley (Fig. 18) had a width reach12 G. Rep. 
ing from the south bank of the present stream to the line of hills which form the northern border of the second plain noted above. The sub-Aftonian drift, if it was ever deposited in this region, cannot be differentiated from the Kansan, but it is certain that at the close of the Kansan stage the old valley was only partially filled with detritus, and an important drainage stream of the subsequent interglacial stage followed the old depression and in part re-excavated the valley. At the beginning of the Iowan stage the re-excavation was far from complete, its amount being represented by the space between the south wall of the valley and the first terrace north of the present stream. The Iowan glaciers deposited only a very thin sheet of drift over this region; but they carried numerous bowlders that are scattered over the whole surface of highlands and lower plains. The plain between the terrace and the channel, and rising only a few feet above the level of the water, is thickly strewn with large Iowan bowlders that have not been disturbed since they were deposited at the level at which they now lie. The present channel is a shallow trough cut in the Iowan drift of this lower plain, and represents the inconsiderable amount of erosion since the withdrawal of the Iowan ice.

The same history is recorded throughout the whole course of the stream in the Iowan drift area, except that during the interglacial stage, between the Kansan and Iowan glacial periods, the stream, for a few miles, was turned aside from the ancient valley and expended its energies in cutting the abandoned, rock-walled channel, already noted, that traverses sections 34 and 35 of Lime Creek township, and a part of section 2 of Mason City. The evidence of the interglacial age of this abandoned channel has been given in connection with the discussion of the topography of the region.

It seems probable that during preglacial and interglacial times the valley of Lime creek accommodated one of the most important streams of northeastern Iowa. After the close of the Iowan stage the Shell Rock river probably took part of 
the drainage waters that had previously found their way through various tributaries into the predecessor of lime creek. At all events there was no pre-Iowan Shell Rock, for. this stream follows no valley; and has cut only a shallow trough in the surface of the Iowan drift. Furthermore the Wisconsin drift, particularly the Altamont moraine, choked up that portion of Lime creek valley which doubtless was produced northwestward from the point at which it crosses the northern boundary of Cerro Gordo county. As a consequence the surface waters have been partly turned into new courses, while those that still find their way from the Wisconsin drift area into the old valley are obliged to wander tortuously among morainic knobs, and over areas in which drainage channels are altogether undeveloped. As a result of these changes the relative importance of the stream following this old valley has been greatly diminished.

Shell Rock river.- The Shell Rock river drains the northeastern portion of the county. It flows almost diagonally through Falls township, entering the county a short distance north of Plymouth and leaving it not far from the northeastern corner of Portland township. In its course in Cerro Gordo county the Shell Rock is a comparatively unimportant stream, receiving few tributaries, and having its drainage area confined to a narrow space on each side of the channel. The Shell Rock, as a stream, is new. There is no evidence of any valley older than the Iowan drift. The channel is cut in the drift plain, which, in places, spreads out on either side of the shallow trough in which the stream flows, and without perceptible slope is lost in the unbroken horizon. Fields that give no suggestion of being lower than the adjacent lands are tilled to the water's edge, and from homesteads established on the brink of the stream the view is equally uninterrupted in every direction. The Shell Rock began to flow in its present course after the Towan ice had disappeared from this region. It is a typical example of a youthful stream. It has cut through the drift and has usually excavated a few feet of 
rock, but the work of valley making is only fairly begun. The amount of rock cutting accomplished by the Shell Rock is less than one-third of that performed by the interglacial stream that excavated the abandoned channel near Mason City. It may not be safe from this fact alone to assume that the interglacial period was three times as long as the period since the close of the Iowan glacial stage, for the attitude of the land is an important factor in determining the rate of channel erosion, but there are other corroborative lines of evidence that justify the belief that the interval between the Kansan and Iowan glacial stages was much longer than the time that has elapsed since the close of the Iowan.

Willow creek is a stream of some importance that, with its numerous branches, drains the region between Mason City and Clear Lake. One of its branches affords an outlet for the waters of Clear Lake during periods of excessive precipitation. In the neighborhood of Mason City Willow creek flows in an old valley that has been subject to the same vicissitudes as the valley of Lime creek. It was excavated to a depth of fifty or sixty feet, and was widened by long continued weathering - of the valley sides in preglacial times. It was partly filled by Kansan and probably by sub-Aftonian drift, and was in part re-excavated during the interval following the close of the Kansan stage. The bottom of the valley received a thin layer of till, and upon it was deposited many large granite bowlders as a result of the invasion of the Iowan ice. The present channel is a small trough with Iowan drift coming down to its margin.

One of the branches of Willow creek, as already noted, carries off any excess of water from the basin of Clear Lake; the other arises in the imperfectly drained sloughs and marshes that alternate with the knobs of drift in the eastern margin of the hilly country north of the lake. Both have their origin in the Altamont moraine, but the main source of the water supplied to the stream is found in the area between the margin of the moraine and Mason City. 
Calmus creek is a stream with a very narrow drainage basin in proportion to its length. It has its origin in a marshy area near the northwest corner of Lincoln township. Its course is nearly parallel to Lime creek, and only a mile or two distant from the larger stream, which it joins in the northern part of Mason City. Except in wet seasons the amount of water carried by Calmus creek is insignificant.

The southern part of the county, east of the moraine, presents extensive reaches of level land in which drainage is not as well established as it is farther north. From large areas the storm waters flow off very slowly, and are finally gathered into a number of small streams that have cut shallow ditchlike channels in the otherwise unbroken plain of Iowan drift. Mount Vernon, Bath, Geneseo, and Pleasant Valley townships are all drained by the numerous small forks of Beaver Dam creek. All of these branches exhibit in the main the characteristics of youthful, prairie streams that have cut only a short distance into the black drift loam. But at a few points some rock cutting has been accomplished, for near Rockwell one of the branches exposes ledges of Owens Grove magnesian shales and limestones; another branch cuts into magnesian shales of the same horizon three miles southeast of Swaledale; in section 35 of Geneseo township the creek flows apparently in a small preglacial, rock-walled valley; and in section 36 of Pleasant Valley township the west branch of Beaver Dam creek cuts into Kinderhook shales and limestones.

Cold Water creek.-Dougherty township is drained by Cold Water creek. This is a small stream in seasons of ordinary rainfall. The headwater branches and the upper portion of the drainage course are defined only as broad swales or sloughs, without any distinct channel cutting through the coarse slough grass sod. Farther down, the channel is better defined.

There are a few drainage channels, not shown on the accompanying map, in the northwestern part of Owen township; there are broad sloughs serving as drainage courses in the eastern part of Owen and Dougherty; but all the southwestern 
part of Owen and adjacent parts of Dougherty, Bath and Geneseo townships, belong to a level expanse of rich prairie land in which drainage has been only imperfectly developed.

Drainage of the morainic belt.-The Altamont moraine, occupying the western townships of Cerro Gordo county, is an area that is practically undrained. Lime creek, as already stated, flows through the northwest corner of Grant township, but it occupies the only definitely marked stream channel in the morainic belt north of Clear Lake.' In this region Lime creek has no tributaries except so far as the debouching sloughs and marshes afford opportunity for drainage of the adjacent areas. For many miles south of Clear Lake there are no drainage channels, except the broad swales that wind in and out among the hills of drift. Indeed the first definitely marked water course in this direction is found near Thornton in the eastern part of Grimes township.

Source of water supply for Clear Lake.-No surface streams flow into Clear Lake. Union and Clear Lake townships are practically destitute of developed drainage courses. The storm waters flow from the hills to the lower levels, but here they move sluggishly along the bottoms of broad grassy swales or through sedgy marshes and, before being gathered into definite streams, are largely lost, partly by evaporation, and partly by percolation into underground channels. The popular belief among the local inhabitants that Clear Lake, which receives no surface streams, must be fed by springs, is doubtless true, for it would be reasonable to suppose that some of the water that sinks into the ground in the billy regions north and south of the lake, would find its way along horizons of sand and gravel into the lake bed. The undrained, saucer-shaped marshes or kettle holes characteristic of the morainic area were noted under the head of topography, and it was also noted that the basin of Clear Lake is only a large. kettle hole, or depression in the drift materials of the moraine, and is not necessarily connected with any special configuration of the underlying indurated rocks. 
Drainage during Wisconsin stage.-Within the limits of Cerro Gordo county it seems clear that few streams of any consequence flowed out from the eastern margin of the Altamont moraine during the period of melting of the Wisconsin ice. The waters from such melting probably for the most part flowed southward along the margin of the ice, inside the moraine, to escape through the marginal ridges of drift at points outside the limits of Cerro Gordo county. Toward the southern extremity of the Wisconsin ice lobe the escaping streams deposited trains and terraces of gravel along their courses. This gravel may sometimes be traced for miles down the valleys in regions outside the lobe of Wisconsin drift, and it may be followed backward into the newer drift region for long distances. In this county, however, there is no evidence of violent stream action and consequent deposition of gravels in connection with the melting of this latest ice sheet, except in the neighborhood of Thornton, and along the west branch of Beaver Dam creek between Thornton and the point at which this stream passes into Franklin county, at the south line of section 36 , Pleasant Valley township. The bold topography characteristic of the moraine farther north gives place in Grimes township to more softened and gentler undulations. There is no marked elevation of the morainic belt above the drift areas on either side.' The creek in quèstion heads well toward the west side of the moraine, and its valley seems to have formed the most important outlet in the county for the escape of waters from the melting ice sheet. Gravels begin in valleys of the several branches of this creek some distance above Thornton. A very large body of gravel occurs where two important branches come together. just below the village. Gravels are strewn all along the creek valley to points beyond the limits of Cerro Gordo county, an important bed occurring in the roadside and adjacent fields a few rods west of the point at which the stream crosses the county line. 


\section{GEOLOGICAL FORMATIONS.}

\section{General Description.}

The geological formations of Cerro Gordo county, while not very numerous, are all of especial interest both from an economic and scientific point of view. The indurated rocks embrace shales and limestones; the superficial deposits are almost exclusively drift. Throughout the greater part of the county the drift covers and conceals the rocks of sedimentary origin. The principal exposures of indurated beds occur along the larger streams and their tributaries in the northeastern half of the county. Exposures of one kind or another are almost continuous along Lime creek throughout its course in the Iowan drift of this region, and Shell Rock river runs over, or between, beds of limestone nearly all the way from Plymouth until it passes into Floyd county above Nora Springs. Near the mouth of Willow creek there are vertical limestone cliffs, and Calmus creek, for a short distance above its mouth, has its channel floored and walled with hard beds of limestone. The following table shows the geological formations recognized in Cerro Gordo county.

\begin{tabular}{|c|c|c|c|c|}
\hline GROUP. & SYSTEM. & SERIES. & STAGE. & SUB-STAGE. \\
\hline \multirow[t]{2}{*}{ Cenozoic. } & Pleistocene. & Glacial. & $\begin{array}{l}\text { Wisconsin. } \\
\text { Iowan. } \\
\text { Buchanan. } \\
\text { Kansan. }\end{array}$ & \\
\hline & Carboniferous, & $\begin{array}{l}\text { Lower Carboniferous, } \\
\text { Mississippian. }\end{array}$ & Kinderhook. & $\therefore$ \\
\hline \multirow[t]{3}{*}{ Paleozoic. } & - & \multirow{3}{*}{ Middle Deronian. } & \multirow{2}{*}{ Lime Creek. } & Owen. \\
\hline & \multirow[t]{2}{*}{ Deronian. } & & & Hackberry. \\
\hline & & & Cedar Valley. & Mason City. \\
\hline
\end{tabular}




\section{DEVONIAN SYSTEM.}

\section{CEDAR VALLEY LIMESTONE.}

The lowest beds seen in this county are the equivalent of the upper portion of the Cedar Valley limestone, as this limestone is developed in Johnson and adjacent counties. A line drawn from Iowa City to Mason City is very nearly parallel to the general line of strike of the Cedar Valley and underlying limestones, and hence, although the geological structure is complicated to some slight extent by local folds, equivalent strata are found at numerous intermediate points. The most persistent life zone in the formation, - a zone which, though presenting some biological and lithological variations, is continuous and well marked over a very large part of the area occupied by Devonian strata in Iowa,--is that containing the branching and spherical stromatoporoids characteristic of the beds numbered eight, nine and ten of the general Cedar Valley section of Johnson county.*

Southeast of the Normal School buildings at Cedar Falls this zone of spherical stromatoporoids occurs in the same relative position to other definitely marked life zones, that it occupies at Iowa City. It overlies the evenly bedded and, in general, non-fossiliferous quarry stone, and this in turn overlies the zone of Acervularia davidsoni. Omitting intermediate points, the stromatoporoid bed is seen above the quarry stone near Marble Rock. It was this same stromatoporoid bed that some years since was worked for the "coral marble" at Charles City. At the locality last named the matrix is more than usually compact, owing to the very perfect cementation of the material with interstitial calcite. The east end of the wagon bridge over the Shell Rock river at Nora Springs rests on the the same bed of Stromatopora. The bed is again exposed in the low bluff of Lime creek at Portland, and is very conspicuous at the top of Lein Brothers' lime quarry in Mason City. The zone of spherical stromatoporoids varies greatly in thick-

\footnotetext{
* This volume, p. 71 .
} 
ness, even within short distances. It varies also in the genera and species of true corals with which the stomatoporas are associated. It varies in the compactness of the matrix and in the perfection of preservation of its fossils. Toward the south the spherical stromatoporoids are followed in ascending order by beds of white, non-fossiliferous limestone. White limestone charged with stromatoporoids growing in flat, laminar sheets or expansions follow the same bed in Cerro Gordo and Floyd counties. In Johnson county the crinkled stems of two species of Idiostroma sometimes prevail to the almost total exclusion of other forms of stromatoporoids; in Cerro Gordo county Idiostroma is usually absent at this horizon, but a very fine stemmed species occurs abundantly in association with the spherical forms, in the upper part of the Kuppinger quarry, a few rods below the mill on Lime creek in Mason City. In Johnson county a Favosites, or Pachypora, with cylindrical habit of growth and very thick-walled corrallites, occurs in the Stromatopora bed; in Floyd and Cerro Gordo, a related, though different, species of the same genus is found sparingly at this same horizon. In Johnson the bed in question frequently contains large coralla of Acervularia davidsoni; in Cerro Gordo Pachyphyllum woodmani and a new species of Diphyphyllum take the place of the Acervularia. Ten or fifteen feet above this horizon, however, in beds of white limestone containing laminar stromatoporoids, Pachyphyllum woodmani is associated with Acervularia inequalis, a very characteristic species, and evidently a highly modified descendant of the species occurring in Johnson county.

\section{TYPICAL" EXPOSURES.}

The characteristics of the Cedar Valley stage in this county may be judged from a study of the following typical exposures. The Kuppinger quarry, in the east bank of Lime creek, between the bridge and the mill dam in the northern part of Mason City, gives the following section: 
FEET.

7. Residual clay and drift

6. Somewhat regularly bedded stromatoporoid limestone in which occurs a small Favosites and some laminar stromatoporas associated with many spherical masses of stromatopora with concentric laminæ of growth.. 3

5. Reef of stromatoporoids consisting largely of spheroidal coralla with concentric, laminated structure; some of the coralla are more than a foot in diameter. In some cases there are great numbers of very fine stems of a species of Idiostroma. Bedding obscure. 5

4. White or grayish, fine-grained limestone, breaking with conchoidal fracture, very compact; ledges ranging from a few inches to more than two feet in thickness. No traces of fossils, or traces few and very obscure

3. Bluish limestone, flexuous and unevenly bedded....... 2

2. Hard, crystalline, grayish dolomite, with occasional streaks of brown and red. In weathered portions of this member the crystals of dolomite are in places very loosely cemented and the rock has the appearance of a friable sandstone. Some beds are vesicular, owing to the solution and removal of fossils. The cavities, however, are lined with crystals to such an extent as to obliterate all evidence of generic or specific characters. Ledges varying from 6 to 36 inches in thickness

1. From floor of quarry to level of stream, covered with talus

The crystalline dolomite, No. 2 of the foregoing section, is called sandstone by the quarrymen and masons of the region. Some of the fossil cavities are evidently due to removal of crinoid stems. The bedding is regular, and the stone may be quarried readily in blocks of serviceable size and shape. No. 3 is rather worthless, owing to the irregularities of bedding and the tendency of the layers to break into shapeless pieces. The white, fine-grained limestone, No. 4, shows very regular bedding, the individual layers generally retaining the same thickness for considerable distances. The rock from this member does not resist the weather as well as the dolomite, * No. 2, though it is used extensively and serves well for many purposes. 
Numbers 5 and 6 together constitute a regular Stromatopora reef. The lower part of the reef shows no bedding planes. At first the stromatoporoids consisted of species growing. in spherical or spheroidal masses from a fraction of an inch to more than a foot in diameter, but later, species growing in flat, laminar masses displaced those with the concentric habit of growth. A few colonies of small cylindrical or branching forms of Favosites and Cladopora occur with the stromatopores, but true corals are very rare at this hori-

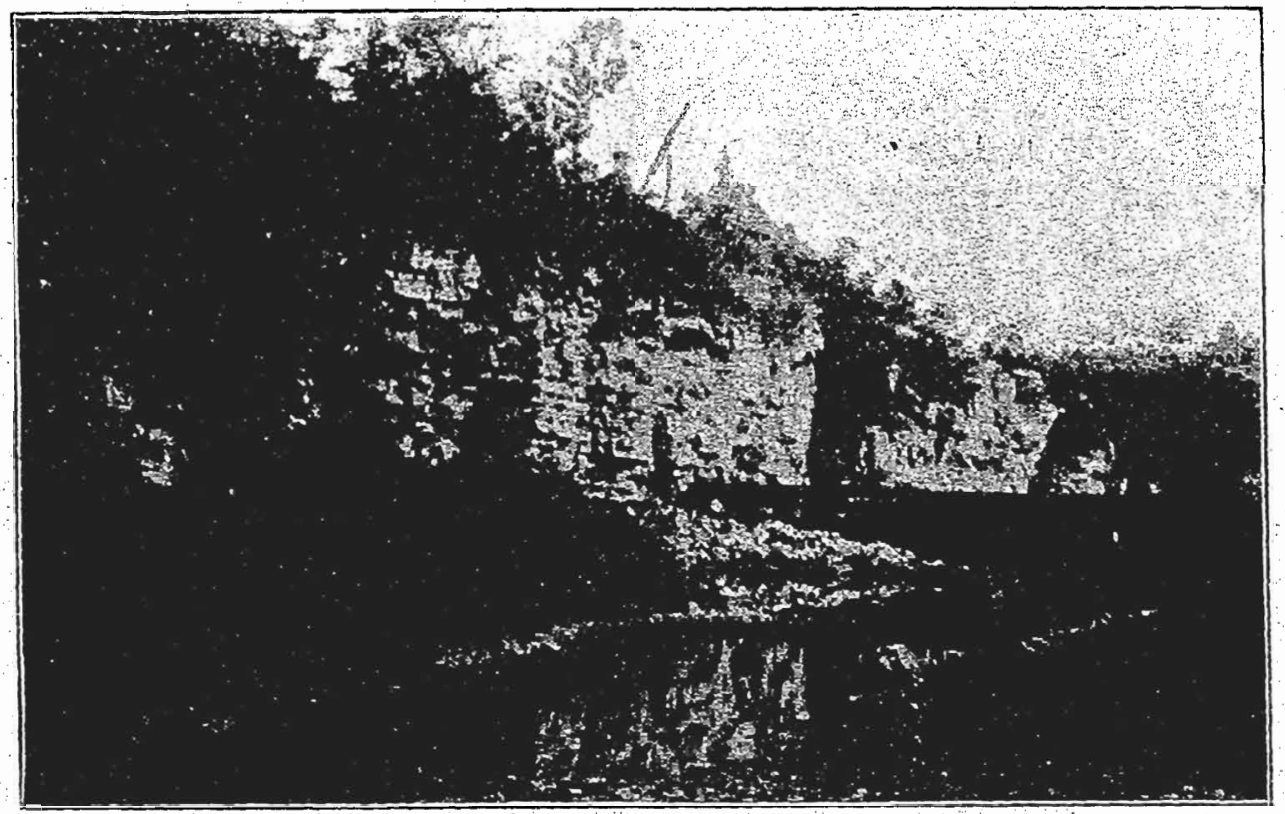

Fig. 19. Natural exposure of Gedar Valley limestone at Parker's mill, Mason City. At this exposure the regular stratification of the beds of this formation, is shown, and their superior powers of resistance to effects of weathering, particularly in the dolomitic phase, are well demonstrated.

zon. The lower surface of the Stromatopora bed is strangely cut by a series of ramifying channels apparently accomplished by streams of water flowing between this bed and the underlying white limestone. The streams, however, dissolved and eroded the roof more than they: did the floor of their underground channels.

The residual clay, No. 7, at the top of the section is very tough and very ferruginous. It has worked its way downward along joints, and from the joints it has spread out horizontally between layers, so that all openings are filled with it to a depth of many feet from the original surface. 
Above the top of the Kuppinger quarry section, the hill rises more than twenty feet. Stromatopores occur at intervals all the way up, but above the level of the quarry the coralla are all of the laminar type. Among the species with horizontal, expansive habit of growth, single coralla may be found measuring from two to five or six feet in diameter. The hillside is partly sodded, and hence no complete section at this point can be made.

Above the mill dam, on the same side of the stream as the Kuppinger quarry, there are exposures of beds 2,3 and 4 ; of the preceding section; and on the south side of Calmus creek, not far from its mouth, the same beds have been quarried to a considerable extent.

At Parker's mill on Willow creek, within the limits of Mason City, the picturesque vertical cliffs (Fig. 19) afford a natural section, in which may be noted.

6. Stromatopora reef, equivalent of No. 5 of the Kuppinger quarry -.................................. 4

5. White limestone, somewhat split up by weathering _. 14

4. Evenly bedded dolomite, in ledges varying from 3 to 30 inches in thickness

3. Inipure dolomite, breaking irregularly by exposure to weather, and containing many cavities lined with crystals of calcite. ................................... 2

2. Crumbling, calcareous, granular bed, light gray in color, with many nodular and branching stromatopores, some Favosites and beautiful coralla of Pachyphyllum woodmani ................................ 1

1. Argillaceous limestone, dark drab in color, homogeneous, but breaks up on exposure to frost

At Lein Brothers lime quarry, in Mason City, the succession of beds already described occurs essentially unchanged. The exposure gives the following section.

FEET.

4. Stromatopora reef, rather definitely stratified, some laminar stromatopores, though most are spheroidal in shape. With the stromatopores occur Pachyphyllum woodmani, an unknown Diphyphyllum and some species of Cladopora 
FEET.

3. Unstratified part of the Stromatopora reef with spheroidal coralla ......................................... 5

2. White limestone .................................. 15

1. Dolomite, blue and gray ............................ 4

The quarries of the Belding Stone Co. are located north of Mason City, in the Se. qr. of Nw. $\frac{1}{4}$ of section 27, Lime Creek township. The beds here show some differences from those observed in the quarries and exposures above described, as will be seen by the following section.

7. Soil and residual clay from a few inches to ............. $2 \frac{1}{2}$

6. White or grayish limestone, shattered into small. pieces; removed as part of the stripping ............. 3

5. White limestone in thin layers $\ldots . . . \ldots \ldots \ldots$

4. White limestone in layers from $2 \frac{1}{2}$ to 10 inches in thickness, good building stone

3. Evenly bedded dolomite, suitable for heavy walls or for cutting into caps and sills; in three ledges 21,10 and 11 inches respectively in thickness .................. $3 \frac{1}{2}$

2. "Blue cap," a bed that quarries out in shapeless, worthless blocks, in two ledges; an impure dolomite. 3

1. Brown, bluish and gray dolomite in eight ledges, varying from 4 to 13 inches in thickness $5 \frac{1}{2}$

The white limestone at the quarry described above lies in thinner layers than the corresponding beds at Mason City. What the quarrymen here call "blue cap," No. 2 of the section, seems to be a local deposit, or at least a local variation in certain layers, in the middle of the dolomitized beds. There is some difficulty in correlating unfossiliferous beds in this region, and the difficulty arises from two causes. First, any given bed may thin out within very short distances, as is well illustrated in figure 20, and ledges that are separated from each other by several feet of strata at one exposure, may be in contact at exposures not far removed. Second, the process of dolomitization has affected the beds differently in different localities, so that ledges of fine-grained, white limestone in one place may be represented by coarse, granular dolomite in another. 
At the quarries of the Mason City Stone Co., in the Ne. qr. of the Nw. $\frac{1}{4}$ of section 34, Lime Creek township, the dolomitized beds have an aggregate thickness of nineteen feet. Above the dolomite are twelve feet of white limestone. A pit sunk below the bottom of the quarry reveals an argillaceous limestone similar to No. 1 of the Parkers' Mill section, and probably its equivalent.

The Mason City Quarry Co. have two openings in the Nw. qr. of Ne. $\frac{1}{4}$ of section 27 of the same township. The work here has not been carried very far back from the natural exposure, and it is probably due to this fact that the layers are in general thinner than at the other quarries described. The beds quarried consist partly of dolomite and partly of the white, non-dolomitized ledges. Certain beds of the dolomite show the effect of weathering much more than others. In ledges twelve to fifteen inches in thickness the cementing material whereby the individual crystals are held together has, in some instances, been removed, and the rock presents the very delusive appearance of a friable, crumbling sandstone, a fact which may in part account for the popular application of the term sandstone to all the dolomitized beds.

At Portland, about four miles southeast of Mason City, the east end of the wagon bridge over Lime creek rests on ledges of limestone forming a vertical cliff. A short distance below the bridge the following section, with the exception of No. 6 , was noted.

FEET.

6. Dolomitized bed with casts of thin laminar expansions of stromatoporoids, exposed between bridge and mill _................ 5

5. Coarse, granular dolomite in thin layers ............ 3

4. White limestone with some stromatopores, the definitely bedded portion of the Stromatopora reef ....- 2

3. Stromatopora reef, with spheroidal coralla, but more perfectly stratified than at most exposures.......... 4

2. White limestone, evenly bedded................. 3

1. Dolomitized limestone in heavy layers ............... 13 
No. 1 in the above section is the equivalent of the dolomite quarried so generally near Mason City. No. 2 represents the fourteen or fifteen feet of white limestone of the Mason City exposures. Nos. 3 and 4 will be recognized as the Stromatopora beds of other localities; while Nos. 5 and 6 are modified representatives of non-dolomitized beds overlying the Stromatopora reef and containing laminated stromatoporoids in the hill above Kuppinger's quarry. Above the bridge the vertical cliff shows the rapid feathering out of certain beds. Strangely enough it is here the most persistent of all the

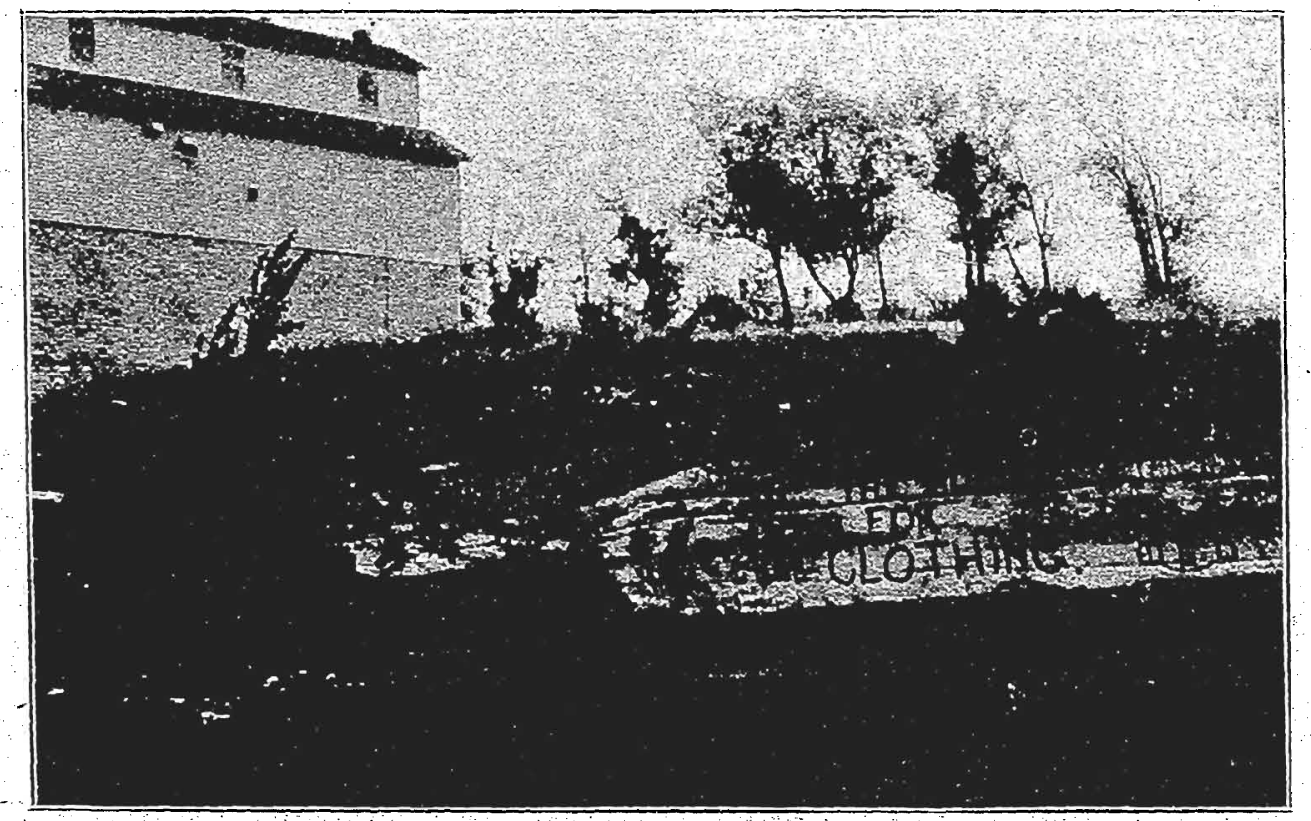

Fra. 20. Exposure of Cedar Valley limestine near Pottand, showing how beds may sometimes "feather out" abruptly. The thinning out of the strata affected is most pronounced near the midale of the viow.

beds (Nos. 3 and 4 of the section) with spherical stromatoporoids, that disappear. No. 5 is bent down abruptly (Fig. 20 ) to rest on the white limestone, and No. 6 , five feet in thickness, appears above it.

Exposures of limestone beds, equivalent to those above described, occur at intervals along Lime creek below Portland, for a number of miles. Less than half a mile below the Portland bridge, bed No. 6 of the Portland section appears in its normal relations, and contains the characteristic laminar 
forms of Stromatoporas. Lithologically, however, its characters are wholly different. It is here an unaltered, white limestone without signs of dolomitization. A mile and a half farther down the stream, in the Se. qr. of Ne. $\frac{1}{4}$ of section 29 , Portland township, an exposure between the creek and the roadway gives-

5. Laminated Stromatopora bed, not dolomitized .......... 5

4. Dolomitized bed, equivalent of No. 5, of Portland section

3. White limestone with some nodular stromatoporoids... 1

2. Stromatopora reef, the unstratified bed of spherical stromatoporids in upper part of Kuppinger's quarry - 4

1. White, evenly-bedded limestone, exposed to level of water . .

For the next two miles and a half in going down stream there are no exposures of any consequence. No beds higher than No. 5 of the last section were seen until the cliff of Lime creek shales was encountered in the northwest quarter of section 35. The shales here come down to the level of the water and the underlying limestone was not seen. There cannot, however, be any great thickness of limestone intervening between the top of No. 5 of the section last described and the base of the shales.

While the bed of laminated stromatoporoids between Portland and the exposures of Lime Creek shales in section 35 of Portland township nowhere exceeds six or eight feet in thickness, the equivalent bed above the Kuppinger quarry has a thickness of about twenty feet. Again, while the shales in Portland township seem to rest on the bed of laminated Stromatoporas, it is still true that this laminated bed is not the highest member of the Cedar Valley limestone. At Nora Springs, a short distance east of the east line of Cerro Gordo county, there are some exposures of very great interest. In the first place the reef of spheroidal stromatoporas is unusually well developed. It rests as usual on white, non-dolomitized limestone. The lower division, crowded with the characteristic spheroidal coralla, is eight 15 G. Rep. 
feet in thickness; the upper portion, showing more definite bedding, is nearly as thick. In the bluff, south of the town, on right bank of the Shell Rock river, there are, above the reef bed, layers corresponding to Nos. 5 and 6 of the Portland section, and these are followed in ascending order by ten feet of soft, yellowish, shaly beds; six feet of light reddish-brown argillaceous limestone, regularly bedded, and quarried for building purposes; five feet of impure, earthy dolomite containing casts of Spirifer and Orthis; and then in the debris on the hillside farther up there are many loose fragments of Actinostroma expansum Hall and Whitfield sp., which marks a horizon not previously noted in this report.

The entire section at Nora Springs would; therefore, be-

7. Horizon of Activostroma expansum, not exposed, but FEET. fragments of Actinostroma are found in debris on hillside

6. Earthy dolomite, with casts of Spirifer, Orthis, etc_. 5

5. Reddish brown, regularly bedded, argillaceous limestone _...

4. Soft, yellowish, shaly beds .................. 10

3. Beds corresponding to Nos. 5 and 6 of the Portland section _..

2. Stromatoporoid reef ....

1. White or light gray limestone, regularly bedded, partly brecciated

West of Rockford in Floyd county there are exposures along Lime creek, which show the earthy dolomite seen near Nora Springs, with casts of brachiopods and other organic types. It is here only a few feet above the level of the water. Above this lies in place the Actinostroma bed, four feet in thickness. Some of the massive coralla occupy nearly the whole thickness of the bed, and have horizontal dimensions of eight or ten feet. The Actinostroma bed is overlain by a thin bed of unfossiliferous white limestone. This is followed by ten feet of yellow laminated shale; and the shale is in turn overlain by a single layer, six feet in thickness, made up of thin, sinuous laminæ of Stromatopora, united at intervals to form a 
mesh-like plexus when seen in vertical section. The plexus of stromatoporoids is embedded in a yellow matrix. About a mile west of the section described above, the well-known Rockford exposures of the Lime Creek shales occupy a position consistent with the view that they rest on the bed last described. At all events nothing higher than this bed is at présent known beneath the Lime Creek shales, and it may, therefore, provisionally be regarded as the uppermost member of the Cedar Valley stage.

Cedar Valley limestones are exposed along the Shell Rock river, at short intervals, from near Plymouth until the stream passes into Floyd county. In the northwest quarter of section 17, Falls township, beds of hard, crystalline, dark gray dolomite are exposed in bank of river with an aggregate thickness of about eight feet. The layers are intersected by many seams, and there are numerous pockets filled with calcite. The strata dip up stream, and beds not seen at the first exposure appear a few yards below. A light gray dolomite, more nearly resembling the dolomitized beds at Mason City, underlies the darker phase. The darker beds are in thin layers, and some near the top of the exposure contain obscure traces of a fossil resembling Strombodes. The beds at this locality are the equivalent of bed No. 5 of the Portland section. This member is, however, much thicker here than at Portland and has some beds heavy and compact enough for use as building stone.

Along the Shell Rock the beds are very much folded. A very sharp arch is seen north of the center of section 17 , and at another fold, one-half mile south, the flank of the arch dips at an angle of $22^{\circ}$. The crown of one of these small arches in section 17 reveals the beds below the dolomite noted above. At level of stream there is a white, regularly bedded limestone which, a few feet higher, is overlain by the Stromatopora reef of the Kuppinger quarry. The white limestone which is fourteen feet thick at Mason City is, near the west line of section 16 , reduced to two feet, and is underlain, as shown in one of the folds, by the Mason City dolomite. 
One half mile above Shell Rock falls there is a small quarry in which the strata at the lower end of the quarry dip southeast at an angle of $15^{\circ}$. The exposure shows.

FEET.

2. White limestone on limb of fold ........................ 6

1. Dolomitized beds ................................... 8

The lower beds of the white limestone have been crushed and partly brecciated, probably in connection with the process of folding. The breccia includes fragments of the underlying dolomite.

Below the wagon bridge at Shell Rock falls there is a good exposure which gives the following section.

W FEET.

4. White limestone containing a few corals, from 1 to $\ldots . .3$

3. Dolomite of good quality, in regular beds _............ 16

2. Irregular bed of impure dolomite, breaking into nodular masses by weathering .......................... 3

1. Argillaceous dolomite $\ldots \ldots \ldots \ldots \ldots \ldots$

No. 1 , in the section just described seems to be equivalent to No. 1 at Parker's mill, while No. 2 at Shell Rock falls seems to represent No. 3 of the Parker's mill section.

At Vermilya's bluff (Fig. 14), in Ne. qr. of section 35, there is an exposure forty feet in height made up wholly of dolomitic beds. The lower twenty feet show no definite bedding planes, and the rock breaks up into angular pieces by weathering. Near the base of the exposure the weatherd surface looks as if the mass were brecciated. The Shell Rock river runs close to the foot of the cliff; the lower beds decay faster than the upper, and so the cliff is undermined to some extent where the stream acts with greatest force. The dolomite in the upper part of the exposure shows more definite bedding. From a half mile to a mile north of Vermilya's bluff there are some picturesque exposures of Cedar Valley limestone, one of which is illustrated in figure 13, but they present no phases not already described.

Exposures of limestone belonging to the Cedar Valley stage occur along Lime creek and its tributaries above Mason City, 
in Lime Creek and Lincoln townships. These show a very interesting progressive modification of certain beds toward the northwest. At the bridge over Blake creek, near the northeast corner of section 28, Lime Creek township, the exposures present the phases observed near Mason City and Portland. A section here gives:

5. Dolomitized phase corresponding to No. 5, of the Portland section

4. White limestone, with some stromatoporoids EET.

3. Reef with spherical stromatoporoids 4

2. Regularly bedded white limestone.................. 10

1. Dolomite, exposed to bed uî ureek ................ 1

Above the bridge the cliff shows a tendency to cavernous undermining, owing to the greater destructibility of the white limestone. The reef of Stromatopora forms the roof of the caverns. All the beds are affected by one of the small folds so common in the limestones of this stage throughout Cerro Gordo and adjacent counties.

About two miles west of the Blake creek bridge, near a small schoolhouse in section 19, the Stromatopora reef occurs at the level of the water in Lime creek, and is followed by the usual beds of white, sparingly fossiliferous limestone. Two and a half miles farther up the creek, in section 14 of Lincoln township, some interesting exposures were observed. There are many strong local dips and short folds. The Stromatopora reef is frequently exposed, and the white overlying limestone is here quite fossiliferous. Among the genera noted were Acervularia, Pachyphyllum, a peculiar Diphyphyllum, Syringopora, Cladopora, Atrypa and Straparollus.

At Lincoln mills, in section 15 , the reef bed is exposed at the level of the water, and the overlying strata contain the same fauna as the corresponding ledges in section 14. Below the mill there are two small folds or anticlines with crests twenty rods apart, and the fossiliferous white limestone is, in places, quite distinctly brecciated. A thin bed of dolomite above the Stromatopora reef is a feature more or less constant at all exposures. It apparently corresponds to bed No. 5 
at Portland. At the east end of the bridge, three-fourths of a mile above the mill, there is an exposure showing a reef rich in true corals. The beds are made up chiefly of masses of Acervularia, Diphyphyllum and Cladopora; yet in many instances the Diphyphyllum has grown around a mass of Stromatopora, and spheroidal stromatoporas make up no inconsiderable portion of the entire deposit. Colonies of this peculiar Diphyphyllum, showing evidences of luxuriant growth under what must have been very favorable conditions, become more numerous as the beds are traced up Lime creek, towards the northwest. Small, dwarfed colonies, with stems rarely more than an inch in length, are found rather sparingly in the reef bed and in overlying layers at Nora Springs, Portland and Mason City. Larger and more vigorous colonies, associated with a greater number of true corals, are furnished by the exposures in the western part of Lime creek, and eastern part of Lincoln township. At the bridge above noted corals are numerous, and the Diphyphyllum occurs in aggregations of long, slender, flexuous stems, with individual coralla measuring more than a foot in diameter. The conditions that gave Diphyphyllum unusual advantages at this locality seem to have favored other corals also, and Cladopora, as well as representatives of other genera, flourished more luxuriantly than further to the southeast.

On the farm of J. S. Wheeler, along the west side of section 10 , and also near the southeast corner of section 4 , Lincoln township, there are a number of interesting exposures which show some phases not before observed. At the Wheeler spring in the Sw. qr. of $\mathrm{Nw} . \frac{1}{4}$ of section 10 , the limestone beds are more completely brecciated, they contain less Stromatopora and proportionally more of true corals than the beds at the bridge in section 15. A little farther up the creek, at a small quarry in section 4, Cladopora is unusually abundant, Diphyphyllum is very common, and slender stems of Idiostroma have taken the place of the massive stromatoporoids. Half a mile above the quarry, the lower part of the beds containing 
Diphyphyllum and other corals has been changed to a coarse granular dolomite, and some of the non-dolomitized layers had been superficially divided into irregular polygonal areas by mud cracks, as if by exposure to atmospheric drying at the time of their formation. All the phenomena seem to imply that the conditions of deposition even in beds that are practically continuous, varied considerably within very short limits.

Along the abandoned channel of Lime creek (Fig. 11), in sections 34 and 35 of Lime Creek township and section 2 of Mason township, the beds as usual exhibit a series of sharp folds; and in the troughs or synclines layers aggregating thirty or forty feet are exposed above the horizon of the Stromatopora reef. In these beds stromatoporoids with laminar expansive habit of growth are very common, and along certain zones Pachyphyllum woodmani and Acervularia inequalis occur abundantly. Among the stromatoporoids with horizontal laminar mode of growth are some coralla of Actinostroma expansum. These coralla are, however, very much smaller than the gigantic coralla of the same species along Lime creek near Rockford, and would seem to indicate growth under less favorable conditions. The argillaceous, dolomitic beds, with casts of brachiopods and other fossils, found below the Actinostroma horizon at Nora Springs and Rockford, seem to be absent in the exposures near Mason City. The evidence of local distribution of certain beds, of rapid thinning out of others (Fig. 20), of faunas more or less localized on account of rapidly varying biotic conditions in the seas in which the beds were deposited, are everywhere apparent, and constitute one of the striking peculiarities of this most interesting region. Only a very generalized section of Cedar Valley limestones of Cerro Gordo and adjacent counties can be given, for the same bed varies in thickness and in lithological characters within short distances, and there is scarcely a single bed that can be said to be constant over any considerable area. The greatest variations occur in the beds above the 


\section{Stromatopora reef (bed No. 5 of the Kuppinger quarry section near Mason City).}

GENERALIZED SECTION OF CEDAR VALLEY LIMESTONES IN CERRO GORDO AND ADJACENT COUNTIES.

FEET.

7. Horizon of Actinostroma expansum and the variable beds above it at Rockford, Nora Springs, and in the hillside north of the abandoned channel of Limo creek near Mason City

6. Argillaceous and argillo-dolomitic beds with casts of fossils in uppermost layers; best developed at section south of Nora Springs; apparently absent at Mason City

5. Beds with laminar stromatoporoids and coralla of Acervularia, Pachyphyllum and a peculiar Diphyphyllum; Diphyphyllum best developed in Lincoln township, in which region the bed contains Atrypa reticularis, more or less of the keds dolomitized at different exposures

4. Reef of nodular or spheroidal stromatoporas, equivalent to beds five and six of the Kuppinger quarry section. This bed attains its greatest thickness east of Cerro Gordo county, as at Charles City and Nora Springs .

3. White or light gray, fine-grained limestone, regularly bedded, unfossiliferous, in ledges ranging to more than two feet in thickness.

2. Dolomite more or less pure and crystalline, generally in compact, regular beds, but very variable in respect to aggregate thickness as well as thickness and composition of individual layers

1. Earthy dolomite, including near the top, at Parker's mill, a thin calcareous bed, with peculiar stromatoporoids and Pachyphyllum woodmani, otherwise unfossiliferous; greatest thickness exposed at Vermilya's bluff (Fig. 1

The entire section of Cedar Valley limestone in the region under discussion lies above the horizon of spirifer parryanus and the reef of Acervularia davidsoni, as seen near Waterloo, Littleton and Iowa City. Beds 1, 2 and 3 of the above general section are represented in Johnson county, if at all, by more or less fossiliferous beds not exceeding fifteen feet in thickness. 


\section{LIME CREEK SHALES.}

At what is popularly known as the Hackberry Grove clay bank, in the northwest quarter of section 35 of Portland township, the Cedar Valley limestones are overlain by the shales and shaly limestones of the Lime Creek stage. On the right bank of Lime creek, in this locality, there is an escarpment, more than seventy feet in height, composed of the Lime Creek formation throughout practically its entire thickness (Fig. 21), In the bed of the creek there are some ledges of

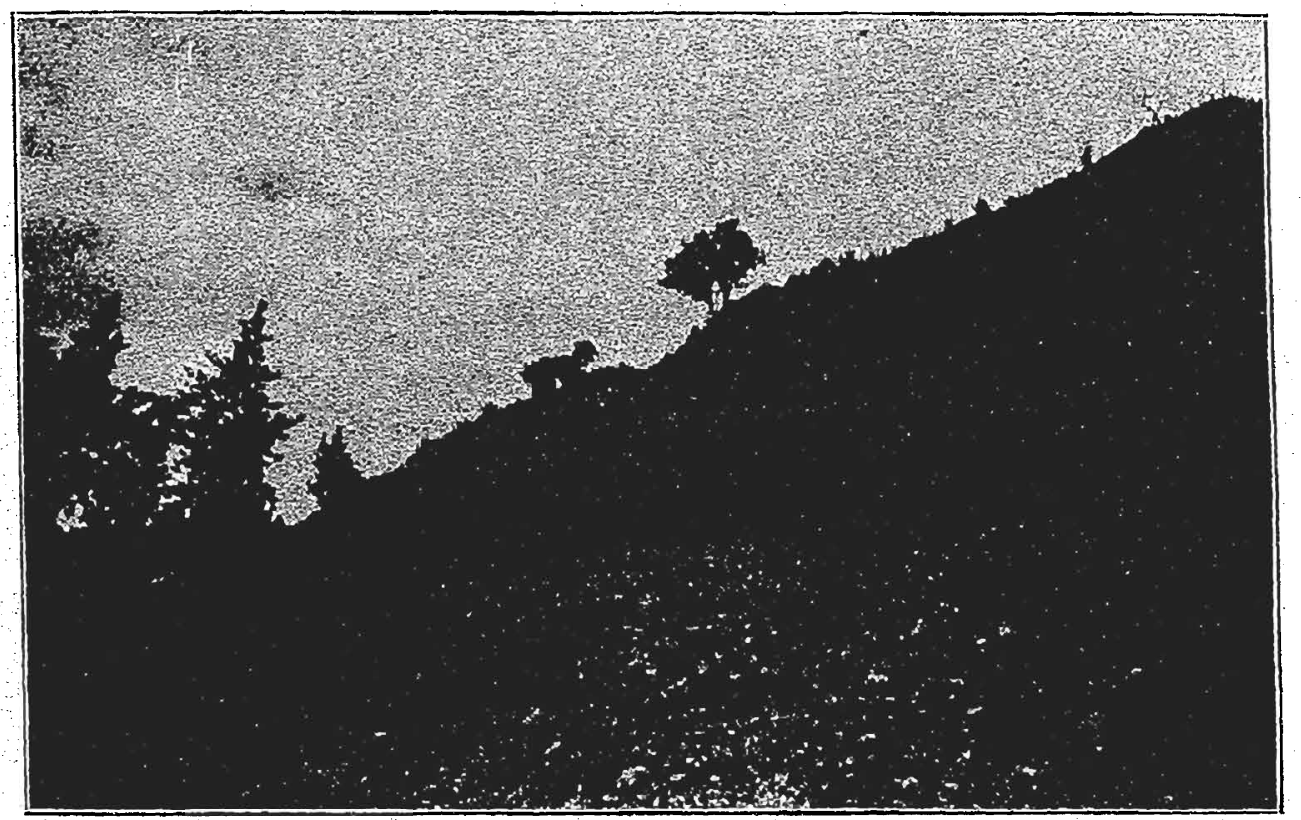

Fig. 21. Exposures of Lime Creek shales at Hackberry Grove. The fossil-boaring member, consisting of calcareous shales and shaly limestones, is seen near the top of cliff. As a result of weathering this member produces a large number of calcareous nodules which are strewn over the talus slope and conceal, to a large extent, the edges of the blue and yellow, arghllaceous, non-fossillferous bsds.

limestone of the Cedar Valley stage, but the shales come down almost or quite to the level of the water, and the talus of shaly material obscures the line of contact between the two formations. The section so far as it can be made out from the weathered surface which, at almost every point, has more or less of overwash from higher beds, is as follows. 
4. Brown, yellowish brown, and gray limestone in sevFEET.

eral layers, containing many of the fossil species found in the underlying shaly limestone; upper bed crowded with a very slender stemmed Idiostroma.... 4

3. Yellowish, very calcareous shales, with bands of shaly limestone; weathering partly into clay and partly into small chips or nodules; very rich in beautifully preserved fossils, particularly brachiopods and corals, a number of interesting species of stromatoporoids being included with the corals .................. 20

2. Yellow argillaceous shales, weathering as does the blue clay below, and free from fossils ............... 10

1. Bluish, argillaceous shales, weathering into a smooth, plastic clay, unfossiliferous _...

Along Owen creek, in section 31 of Portland township, there are a number of exposures of the same shales seen at Hackberry Grove. There are also exposures in the roadway north and south of the point at which this creek crosses the east line of section 31 . South of the creek, near the east side of the section, there is a natural exposure in the rather steep hillside, which shows the blue unfossiliferous shales near the base, and the calcareous fossiliferous beds above. The formation seems to be, on the whole, somewhat thinner here than at Hackberry Grove, but the succession of beds is the same and the fauna of the fossiliferous stratum is identical. A road cutting on the section line, a few rods southeast of the exposure, reveals the calcareous, fossil-bearing beds. At the exposure on the hillside there is evidence of a strong dip to the west; in the road cutting the dip seems to be to the south. The shales here dip in fact to the southwest, the southern component being a little more than fifty feet to the mile, and the western component equally as great. Following up the creek there are outcrops of the shales at intervals; and owing to the fact that the valley slopes to the northeast while the shales dip in the opposite direction, only about half the thickness of the shaly fossil-bearing member of the section rises above the level of the creek bed at the first outcrop west of the halfsection line. Farther up, the Idiostroma-bearing limestone- 
No. 4 of the Hackberry section-appears nearer and nearer the bottom of the valley, until finally at a small quarry near the west line of the section, this limestone occurs in the very bed of the creek and forms the floor over which the water flows. A quarry opened in the low bluff at this point works beds that lie above the uppermost member of the Hackberry Grove section. The layers exposed by the quarry are yellowish in color, and are made up of magnesian shales and soft argillaceous dolomites. Only a few of the layers furnish building stone. Fossils occur, but they are all in the form of mere casts or impressions. So far as they can be identified the fossils are the same as species found in the calcareous shaly layers below the Idiostroma-bearing limestone, and therefore the beds exposed in the quarry must be regarded as the upward continuation of the Lime Creek formation. The thickness of the magnesian shales and argillaceous dolomites at the quarry is about thirty feet. In the talus-like debris on the hill slope above the quarry there are fragments of limestone along with specimens of a species of Acervularia not before observed. There are probably twenty feet of strata indicated above the level of the quarry, and this too may, for the present, be regarded as a continuation of the same formation. Since no Devonian beds, known to be higher in the geologic column than the Acervularia-bearing limestone above the Owen creek quarry, were seen at any point, the strata belonging to the Lime creek stage may be arranged as follows.

GENERAL SECTJON OF LIME CREEK SHALES.

FEET.

6. Calcarcous beds, light gray in color, containing a hitherto unnoted species of Acervularia

5. Magnesian shales and argillaceous dolomites, with impressions and casts of fossils among which are very large individuals of Naticopsis gigantea ...... 30

4. Limestone with slender Idiostroma (No. 4, of Hackberry section)

3. Fossiliferous calcareous shales (No 3, at Hackberry) - 20

2. Yellow, non-fossiliferous shales .................. 10

1. Blue, non-fossiliferous shales ..................... 40 
Nos. 1, 2 and 3 will hereafter be referred to as the Hackberry beds of the Lime creek formation; Nos. 4,5 and 6 will be called the Owen beds.

The blue shales, No. 1 of the Hackberry beds, are exposed at a few points in the county. The best exposure is the typical one at Hackberry Grove. They outcrop at two of the exposures on opposite sides of Owen creek, in the east half of section 31 of Portland township. They are again seen at the foot of a low bluff, on the south side of Willow creek, in the southwest quarter of section 5 of Mason township. They are exposed artificially in the clay pit of the Mason City Brick \& Tile Co. at Mason City. The yellow shales, No. 2, have about the same exposures. The shaly, calcareous fossiliferous division, No. 3, is seen at Hackberry Grove, where the largest and most important exposure occurs. There are half a dozen or more typical outcrops along Owen creek in the southwest corner of Portland township, and the typical phase of the same bed, rich in beautifully preserved fossils, is seen on a hillside in the Se. qr., Ne. $\frac{1}{4}$ of section 24 in Owen township. Roadways, either by natural erosion or artificial excavation, have been cut into this stratum along both the east and west lines of section 32 of Portland township, and on the county line, along the east side of section 24 in Owen. The same phase is found near the southeast corner of the county.

At least two phases of the fossil-bearing stratum of the Hackberry beds must be distinguished. The typical phase is a calcareous shale interstratified with shaly limestone and very rich in fossils. The brachiopods and corals are preserved in remarkable beauty and perfection. Representatives of the Mollusca usually occur in the form of casts. This phase is seen at Hackberry Grove, along Owen creek at Owen's Grove, and at all outcrops south of the two points mentioned. As this bed is traced northwest from Hackberry and Owen's Grove, it assumes a new phase, becoming more magnesian and preserving fossils only in the form of impressions or imperfect 
casts. This magnesian phase is seen above the blue shales, along Willow creek in the western part of section 5 of Mason township. It is exposed in the railway cut west of the Chicago, Milwaukee \& St. Paul depot, in Mason City, within a few rods of the point where the yellow and blue unfossiliferous shales are worked by the Mason City Brick \& Tile Co. It crops out at a dozen points or more in the road between Mason City and Clear Lake, becoming, however, less shaly and more dolomitic toward the west. The last exposure noted in this direction occurs near the east line of section 17 in Lake township, about two miles east of Clear Lake. The beds here are a moderately firm and rather crystalline dolomite and have been quarried on a small scale for building. stone. All the fossils, as is quite usual in dolomites, are casts, but owing to the greater firmness of the rock they are much better preserved than in the more shaly portions near Mason City.

The outcrops of the Owen beds occur chiefly in the southeastern part of the county. Only a few of the more characteristic exposures need be mentioned. That which may serve as the type, the quarry on Owen creek near the west line of section 31, Portland township, has already been mentioned. There is another excellent exposure of the same beds, also quarried for building stone, about a mile and a half southeast of the Owen creek quarry. At this point (Nw. qr. of Sw. $\frac{1}{4}$ of section 5, Owen township) the rock is harder, and it lies in thicker layers than at the typical exposure. The level here is nearly the same as that at which the fossiliferous member of the Hackberry beds occurs a little more than a mile directly north, at which point, as already noted, the road cuts through this bed, exposing nearly its entire thickness and revealing a southerly dip of more than fifty feet to the mile. This dip carries the Hackberry shale below the bottom of the small valley in the side of which the outcrop in section 5 of Owen township occurs. At this last named locality the quarry stone is overlain by a light colored limestone containing the species 
of Acervularia characteristic of this horizon. This limestone is exposed in the road for some distance south of the quarry.

Owen beds, exhibiting the yellow magnesian phase overlain by limestone, are exposed on and near the county line in the southeast quarter of section 25 in Owen township. North of Rockwell they are seen along the west line of section 35 of Bath township; and in the neighborhood of Rockwell in Geneseo township, there are outcrops of considerable interest. They afford here a quarry stone of fair quality, and beds have been worked at a number of points. The typical fossils are large casts of Naticopsis gigantea $\mathrm{H}$. and W., in the magnesian beds, and Acervularia (species undetermined) in the overlying lighter limestone. In the upper part of the quarries, above the dolomitized beds, there are many colonies of a thin laminar stromatoporoid. There is a small quarry in section 26 of Geneseo township and near the southeast corner of section 36 , on land of Mr. Bokemeier, there are two or three exposures that have been quarried to some extent. These exposures offer nothing especially new. The beds consist of soft, yellow, magnesian shales with interstratified beds of earthy dolomite and are overlain by limestone. In the magnesian beds casts of very large individuals of the form described by Hall and Whitfield as Naticopsis gigantea occur, as they do at all the other exposures of beds belonging to this horizon, and with them are casts of Spirifer whitneyi and some other characteristic brachiopods of the Lime creek stage. A portion of a large Cyrtoceras, flattened by pressure, was found in the loose material of the quarry, and specimens of the large, gastropod with elongated spire, that has been erroneously described* as Loxonema gigantea, occur occasionally.

* Am. Nat. vol. 22, p. 445, Phila, 1888 The forms described as Loxonema gigantea, L. crassum and $L$. owenensis, are not even distantly related, generically, to Loxomema. In the structure and composition of the substance of the shell, the great thickness of the shell, the characteristics of the aperture, and the surface markings, they belong with the peculiar form called Naticopsis gigantea by Hall and Whitfield; and it is quite possible that this group will have to be assembled u nder a new generic description. The proposal of a new name and definItion of the genus is, however, left for those who have the requisite expert knowledge and who find delight in such things. 
FAUNA OF LIME CREEK SHALES.

The fauna of the Lime creek shales is of such general geological interest as to deserve more than a passing notice even in a work devoted chiefly to the economic side of geology. The following list of species which might be greatly extended, gives the more common and conspicuous forms. It will afford some knowledge of the general aspect of this most interesting assemblage of Devonian types.

Stromateporella incrustans Hall and Whitfield.

S. solidula $H$. \& W.

Parallelopora planulata H. \& W:

Acervilaria inequalis $\mathrm{H} . \& \mathrm{~W}$.

Crathophyllum solidum H. \& W.

Pachyphyllum woodmani White.

P. solitarium H. \& W.

Campophyllum nanum H. \& W.

Ptychophyllum ellipticum $\mathrm{H}$. \& W.

Strombodes johannis H. \& W.

S. multiradiatum H. \& W.

Cystiphyllum mundulum H. \& W.

Aulopora saxivadum H. \& W.

$A$ iowensis H. \& W.

Alveolites rockfordensis $\mathrm{H} . \& \mathrm{~W}$.

Crania famelica $\mathrm{H}$. \& W.

Stropheodonta arcuats Hall.

S. calvini Miller.

S. canace H. \&W.

S. variabilis Calvin.

S. perplana var. nervosa Hall var.

Strophonella reversa Hall.

S. hybrida H. \& W.

Orthothetes chemungensis Conrad.

Productella hallana Walcott.

Orthis (Shizophoria) impressa Hall.

Camarotcechia contracta var. saxatilis Hall.

Pugnax altus Calvin.

Pugnax ambigutus Calvin.

Gypidula comis Owen.

Dielasma calvini H. \& W.

Atrypa reticularis Linnæus.

Atrypa aspera var. hystrix Hall var.

Spirifer whitneyi Hall.

S. orestes H. \& W. 
S. fimbriatus Conrad.

S. macbridei Calvin.

S. cyrtinaformus H. \& W.

S. hungerfordi Hall.

Crytina hamiltonensis var. recta Hall.

Paracyclas sabini White.

Paracyclas elliptica Hall?

Naticopsis gigantea $\mathrm{H}$. \& W.

Orthoceras sp.

Crytoceras sp.

Goniatites sp.

About the only fish remains observed were fragments of plates of Arthrodires. The Goniatites mentioned is represented by a single imperfect specimen collected by Harold $M$. McLaughlin, of Mason City. It indicates a species as large as $G$. ixion Hall, but differing from that species in the character of the siphonal lobe.

As shown in $1878^{*}$ the lime creek fauna is more closely related to the fauna of the Independence shales than to any other. The following characteristic species are common to the two formations.

Pachyphyllum solitarium H. \& W.

Stropheodonta arcuata Hall.

S. calvini Miller.

S. canace H. \& W.

S. variabilis Calvin.

Strophonella reversa Hall.

Productella hallana Walcott.

Orthis (Schizophoria) impressa Hall.

Pugnax altus Calvin.

$P$. ambigutus Calvin.

Atrypa reticularis Linne.

Atrypa rspera var. hystrix Hall var.'

Cyrtina hamiltonensis var. recta Hall.

To this list may possibly be added Gypidula comis. This species is found typically developed in the Wapsipinicon stage, but in general outline and expression it here differs conspicuously from the forms referred to this species from the Lime creek formation. The species does not occur in the Cedar

* CaIrin, Bull. U S. Geol and Geo. Sur., vol. IV, pp. 725-730. Washington, 1878. 
Valley limestones. In the Independence shales, however, there is a small species, Gypidula munda Calvin, that differs from the Lime Creek form chiefly in its smaller size. The form referred to above as Pugnax altus is a small acuminate variety of Pugnax pugnus Martin; and while this last named species occurs in the State Quarry beds of Johnson county, it is there strikingly different from the identical varietal forms that occur in the two shaly formations under consideration.

A few species, some of them, however, having so wide a range geologically and geographically as not to be very characteristic, are common to the Cedar Valley limestones and the overlying shales. These embrace:

Acervularia inequalis H. \& W.

Pachyphyllum woodmani White.

Productella hallana Walcott.

Orthis (Schizophoria) impressa Hall.

Atrypa reticularis Linne.

Spirifer whitneyi Hall.

Spirifer fimbriatus Conrad.

Cyrtina hamiltonensis var. recta Hall.

Acervularia inequalis and Pachyphyllum woodmani are found in a zone immediately beneath the Lime Creek beds, and not very far outside the geographical area in which the shales are distributed. Productella hallana and Spirifer whitneyi have been collected, but in very small numbers, in the Cedar Valley limestones near Iowa City. The others range through several life zones, and are found distributed over large areas. Faunally, therefore, the relations of the Lime Creek shales are more intimate with the Independence shales than with any other formation in Iowa. During the time represented by the shales and limestones which lie between the Independence and the Lime Creek shales the peculiar fauna of the lower shale horizon, adapted to life on a muddy sea bottom, persisted in some congenial localities at present unknown, suffering in the mean time only a very slight amount of modification, and again appeared, reinforced by a number of other species, 14 G. Rep. 
when the sea bottom offered conditions favorable to its success.

The fauna of the Owen beds is much less prolific in species than that of the Hackberry beds. The form called Naticopsis gigantea $\mathrm{H} . \& \mathrm{~W}$. is apparently more common than in the underlying zone. With it, as already noted, are associated one or two related species with more elongated spires. There are some casts and impressions of brachiopods and other types, but no particular species can be said to be common. A species of Acervularia with thin non-corrugated walls bounding the individual corallites, and with thin septa, few in number and rather sparingly carinated, occurs in limestone above the magnesian beds. Probably the highest zone of the Owen beds is exposed along Beaver creek, in the southeast quarter of section 35, Geneseo township. Here the rock is a rather hard, brittle limestone, resembling some phases of the Cedar Valley stage, and the rather meager fauna embraces some stromatoporoids, a Cladopora and a rather small form of Atrypa reticularis.

\section{CARBONIFEROUS SYSTEM.}

\section{KINDERHOOK STAGE.}

Strata of the Kinderhook stage of the Lower Carboniferous series are exposed along Beaver Dam creek in section 36 of Pleasant Valley township. Where the county line road, on the south side of the section, crosses the creek, the Kinderhook beds are composed of soft, shaly, magnesian limestone; but in Franklin county, a short distance south of the road, beds that occupy a higher position are exposed in the sides. of the valley, and these are firm enough to afford quarry stone suitable for bridge piers, foundations and other rough masonry. An Athyris resembling Athyris proutii Swallow, a Productus related to $P$. punctatus, and Orthothetes sp. are the characteristic fossils. The next exposures east of the Kinderhook outcrops are the Devonian beds already noted on Beaver creek. The contact of the Carboniferous with the Devonian was not 
observed, but the line of overlap lies between the two localities last named.

\section{PLEISTOCENE SYSTEM.}

There are few good sections of the Pleistocene deposits of Cerro Gordo county available for study, but this disadvantage is partly compensated for by the manner in which the different formations of this system are deployed and present themselves at the surface in different parts of the county. An area approximately equal to three-fourths of the county, embracing almost all excepting the western tier of townships, is occupied, superficially, by Iowan drift, while the townships excepted are characterized by deposits of Wisconsin age. It is very probable that the Iowan drift was spread over the entire area and now underlies the Wisconsin in the western townships; and it is also probable that long before the Iowan glaciers invaded the state, drift of Kansan age formed the superficial deposits of this entire region. Here, however, the Kansan drift is not well differentiated as a distinct sheet of till, as it is in Johnson and adjacent counties. Of the subAftonian or pre-Kansan drift there is at present no reliable evidence.

\section{KANSAN DRIFT.}

The Kansan drift, although not differentiated in actual sections, is indicated in two ways. First, the preglacial valley of Lime creek is in places from one to three miles in width, and there is very conclusive evidence that it had been nearly filled with a considerable body of drift, and was later partly re-excavated, before the Iowan till was deposited. This evidence is given in some detail in connection with the discussion of the genesis of the topography of the Lime creek valley. Second, at many points in the valley of Lime creek, and along some of the tributary streams, there are extensive deposits of gravel underlying drift of Iowan age. This gravel is composed of drift pebbles mingled with more or less of sand, and it had its origin in an old drift sheet which preceded the 
Iowan age. The gravel beds may reasonably be correlated with the Buchanan gravels, and the drift sheet from which they were derived may in the same way be correlated with the Kansan. At all events Cerro Gordo county was overspread by a sheet of till older than the Iowan, and the fact that the Kansan stage was the time of maximum glaciation for this continent, and that, during this stage, the ice sheet was practically continuous over the whole glaciated area from the eastern part of Nebraska and the Dakotas to the Atlantic ocean, would lend support to the view that a part at least, if not all, of this earlier drift belongs to the Kansan age. This does not preclude the possibility of a pre-Kansan or subAftonian invasion of the region by glacial ice. Indeed the known distribution of the pre-Kansan drift renders it extremely probable that Cerro Gordo county has two sheets of till older than the Iowan.

\section{BUCHANAN GRAVELS.}

The stage of the Buchanan gravels* is represented by extensive gravel deposits in the valley of Lime creek, and by similar deposits along Blake creek and other tributaries. The main bodies of these gravels were deposited in the partly filled preglacial valley of Lime creek. They underlie a large area on the north side of the stream in Lime Creek and Lincoln townships, occupying the level space (B. Fig. 18) south of the highlands (c) which mark the boundary of the preglacial valley. Good exposures are seen at various points north of the road near Lincoln mills, in section 15 of Lincoln township; and in section 10 of the same township there is a pit, worked for road material, that shows above the gravel a thin sheet of Iowan till with characteristic granite bowlders. Wells and other excavations reveal underlying gravel throughout the whole plain south of the highlands already noted. Blake creek in Lime Creek township has cut its valley through the

\footnotetext{
* The Buchanan Gravels, etc, by Samuel Calvin. Am. Geologist, vol. XVI, p. 76. Feb, 1896. Journal of Geology, Editorial, vol. IV, $p$ 872. October-November, 1896. Fifth Annual Report of the State Geologist (this volume), p. 18 .
} 
thin sheet of Iowan till and exposed the same gravels at various points, good outcrops occurring north of the center of section 16. The higher ground on either side of the shallow valley is, in places, thickly strewn with Iowan bowlders.

A rather sandy phase of the gravels is worked extensively for ballast by the Chicagō, Milwaukee \& St. Paul railway, in the southwest quarter of section 2 of Mason township. There are exposures in the northern part of Mason City on the west side of Lime creek, and from one of these, located near the greenhouse, workmen some time ago obtained the horn of a reindeer. The gravel in the northern part of the city is rather coarse, but just east of the city the material is much finer, and the beds have been worked for building sand. The sand, however, contains more or less of gravel; and near the base of the deposit there are many large slabs and fragments of limestone. Gravel beds of varying degrees of fineness are distributed along the valley of Lime creek throughout its whole extent in Cerro Gordo county. The old preKansan valley, only partially filled with drift, seems to have carried torrents of water from the melting Kansan ice. The torrents were loaded with gravel and sand, and doubtless with finer material, and the coarser fragments were deposited to form the gravel beds above described. After the Kansan ice had retreated beyond the limits of the drainage area tributary to this valley, when the stream had shrunk to the dimensions required to carry off the normal precipitation, and when the current was no longer loaded, erosion attacked the gravel beds and re-excavated a portion of the valley down to the level of the plain represented in profile at A, Figure 18.

The beds of gravel and sand are the only deposits seen in the county that can as yet be referred to the Buchanan interglacial stage, but the abandoned channel of Lime creek (Fig. 11) represents a piece of rock erosion accomplished during this interval. This channel is not wide when compared with the preglacial valley of the same stream, but, from the summits: of the adjacent hills to the rocky floor that supports a 
heavy bed of peaty humus and Iowan drift, its depth exceeds fifty feet. As pointed out in discussing the topography of the county, the time interval which the abandoned channel represents was probably long even as compared with all postIowan time.

\section{IOWAN DRIFT.}

Drift of the Iowan stage constitutes the surface materials over almost three-fourths of the county. This drift sheet varies very greatly in thickness, for there are areas in which it seems to be represented only by typical bowlders without an appreciable quantity of finer detritus; and there are other places where its thickness may exceed a score of feet. Where well developed it presents the usual characteristics of a yellow clay mixed with more or less of sand and gravel, with scarcely more signs of oxidation and ferrugination at the surface than at greater depths, its calcareous constituent unaffected by leaching, even at the grass roots, and bearing bowlders of undecayed, light-colored granites. The bowlders often attain enormous size. Figure 15 illustrates one of the great masses of granite plentifully sprinkled over the area occupied by Iowan drift. Much larger blocks, however, than the one illustrated are sometimes seen. One of these, composed chiefly of large reddish crystals of feldspar, protruded a foot or two above ground in Kirk's addition to Mason City. An effort was made to remove it by blasting it to pieces; but after taking it out to a depth of twelve feet, and finding its dimensions increasing all the way down, the effort was abandoned. When the work stopped the size of the exposed surface was eighteen feet in leng̀th by sixteen feet in width. The depth or thickness is unknown, A still larger bowlder of the same kind of granite is seen near the west line of the southwest quarter of section 7, Portland township. The dimensions above ground are twenty-five feet in length, twentythree feet in width and eleven feet in height. A smaller mass of the same granitic species is only a few feet removed from the larger one, and it is possible that when they started on 
their journey the two constituted but a single block. Bowlders varying in size from three to five, or even eight feet in diameter are very common.

The Iowan drift, in this region, seems to have been on the whole rather meager in amount, and it now forms a thin sheet of till conforming to the inequalities of the pre-Iowan surface. It is spread over the uplands and higher plains of the area in which it is distributed; it covers the beds of gravel at a lower level within the limits of the preglacial valleys; it descends upon the low plains adjacent to the streams in the relatively narrow valleys formed by interglacial erosion; and it partly fills the abandoned interglacial channel north of Mason City. At the Hackberry exposure of Lime Creek shales the Iowan drift, undisturbed since it was deposited, covers a low plain north of the stream; while south of the stream it is spread over a plain more than seventy feet higher, which plain begins at the summit of the Hackberry escarpment. In sections 16 and 17 of Lake township, in 24 of Mason, in 24 of Owen, and at other points in the county, this drift sheet rises from low plains or valleys to spread a thin mantle over preglacial ridges composed of Lime Creek shales.

The scantiness of the materials in the Iowan drift is well illustrated on the higher lands, in the area underlain by beds of the Lime Creek stage. The region south and west of Mason City is plentifully strewn with Iowan bowlders, but the drift is so thin that the soil through which the farmer drives his plow is in many places made up of decomposed shales of Devonian age. The same is true of the fields that extend south from the summit of the Hackberry exposure in section 35 of Portland township. The Iowan bowlders are imbedded in Lime Creek shales, and the ordinary clayey till seems to be almost entirely absent. About Rockwell the Owen beds of Lime Creek age protrude at intervals through the drift over areas of considerable extent, notwithstanding the fact that numerous bowlders clearly testify that the whole region was once overrun by Iowan glaciers. It is also true that in the 
localities noted the materials of the drift sheets older than the Iowan are equally scanty.

\section{WISCONSIN DRIFT.}

There are at present no known deposits in Cerro Gordo county referable to the interglacial stage (Toronto?) between the Iowan and the Wisconsin. Deposits piled up by the Wisconsin ice sheet are, however, conspicuous features of the Pleistocene formations in the western townships of the county. The area has been described in connection with the subject of topography. The deposits themselves consist of the ordinary materials that elsewhere make up the Altamont moraine. Fine glacial clay predominates, but the clay contains some sand, a great many pebbles, and a less number of bowlders ranging from a few inches to a foot or two in diameter. The clay is a lighter yellow than that of the Iowan drift, and it contains a large amount of calcareous matter. The pebbles are fragments of crystalline rocks with which are mingled a very large proportion of pieces of limestone. In places the limestone fragments seem to predominate with respect to numbers, and many of them contain traces of fossils. The bowlders are, as a rule, smaller than those scattered over the Iowan area; they are darker in color, with a tendency to bluish shades; and a large proportion of them are intersected with seams and veins of trap. The Wisconsin drift, therefore, is readily distinguished from the Iowan by its paler, more calcareous clay, its great numbers of limestone pebbles, and its smaller, darker colöred bowlders which often are weathered into very erratic shapeš. The irregular weathering is due to the presence of intrusive veins which render certain parts of the individual bowlders harder and more resistant than the rest. Limestone pebbles, which are so common and characteristic in the Wisconsin drift are very rare in the Iowan.

The hills and knobs of drift constituting the Altamont . moraine presented to the first settlers of the region the 
appearance of being made up of gravel. The gravel was, however, limited, as tests have demonstrated, to a thin superficial layer. The whole body of Wisconsin drift is rich in pebbles. On the steep slopes of the morainic hills rain erosion, acting through many centuries, removed the finer glacial clays and sands from the surface stratum of drift; and the pebbles, too large to be moved, were left as a thin residual layer over the tops and sides of the irregular moranic bosses of drift.

Eskers and valley trains.-The hills and bosses that characterize the moraine become less pronounced in the southern and southwestern part of Grimes township. Indeed in the southwestern part of this township the hills fade into the level, characterless topography peculiar to the central areas of Wisconsin drift. In this level region, parts of which are still very marshy, are the initial branches of the south fork of Beaver Dam creek which, fiowing southeast, finally emerges upon the area of Iowan drift. The valley of this creek seems to have been the chief outlet in Cerro Gordo county for the waters resulting from melting of the Wisconsin ice. Accordingly, near Thornton, about half a mile southwest of the village, there is a well defined esker in the form of a long ridge of gravel resting on Wisconsin drift. This gravel, as might be inferred from its origin, contains a large proportion of limestone pebbles. The ridge, which is three-fourths of a mile in length, trends a few degrees south of east. It is not quite parallel to the present drainage. The course of the glacial stream, to which it owes its origin, was determined by conditions affecting the margin of the Wisconsin ice, and not by the conditions that determined the position and course of the modern streams.

In the neighborhood of Thornton the streams flow over beds of the same kind of gravel found in the esker. A heavy accumulation occurs below the village near the point where two branches flow together. Trains of gravel follow the creek valley beyond the limit of the moraine, well out into the 
region of Iowan drift. The last gravel beds of this age in Cerro Gordo county occur along the south line of section 36, Pleasant Valley township, where the stream passes into Franklin county.

POSTGLACIAL DEPOSITS.

More recent deposits of the Pleistocene period are found at a number of localities, particularly in the Altamont moraine. Peat has accumulated, and is still accumulating, in the kettle holes and undrained basins of the moranic belt. The peat bed marking the site of an old lake basin, already noted as one of the topographic features of section 24 of Union township, and adjacent sections, affords a typical illustration of such deposits. Near the southwest corner of section 34 of the same township, a basin of some extent, filled with peaty material mixed with rain wash from the surrounding hills, was dry enough for cultivation during the past season. The black, peaty soil, turned by the plow, abounds in shells of pond snails belonging to the genera, Physa, Limnæa and Planorbis, and a well dug at some distance from the margin of the basin reveals a thickness for the deposit of six or eight feet, and charged with shells of the same species throughout its entire extent. It is needless, however, to multiply examples. Peat beds, complete or in process of formation, occur in almost every quarter section of the broad belt covered by the moraine. They are particularly numerous in portions of Union and Grimes townships.

The beds of sand around the east end of Clear Lake are a product of forces that have been operating continuously since the retreat of the Wisconsin glaciers. The sand is not derived from decay of siliceous rocks in place, or in the immediate neighborhood, for no such rocks are found within some hundreds of miles of the lake. It must be regarded as the residuum left after removal of the finer silt from a large body of glacial till, waves and meteoric waters being the agents of such removal. The ridge of sand and gravel which has 
converted a former part of the lake into a detached marsh west of the Assembly grounds, is a comparatively recent deposit due to expansion and shoreward creeping of lake ice during the many successive winters since the lake was born. After terrestial vegetation gained a foothold on the ice-heaved ridge, the further growth of the deposit may have been aided by the effect of winds, for drifting dust and sand would tend to lodge in every spot that afforded the requisite degree of shelter.

There are no bodies of alluvium worthy of record along any of the streams of Cerro Gordo county.

\section{SOILS.}

The soils of Cerro Gordo county are mostly of the drift type. In the area of Iowan drift, the land is comparatively level, and the soil is a deep black loam, rich in organic matter, and with sufficient admixture of sand to make it warm, mellow and easy of cultivation. A typically level stretch of farming land occurs in the southwest part of Falls and adjacent parts of Lime Creek and Portland townships. A farm embracing an entire section may have its surface so perfect a plane that every part of it may be viewed from some central point; and every square foot of such a farm may be cultivated. Notwithstanding the apparent level, there is no evidence that these lands suffer from lack of drainage. There is some slope to the surface, and the subsoil is so porous as readily to carry off any ordinary excess of storm waters. Similar level areas of exceptionally rich farming lands, susceptible of high cultivation with the least conceivable amount of labor, occur in Owen, Dougherty, Bath, Geneseo, Mount Vernon, Pleasant Valley and other townships. Adjacent to the streams there are lands with greater slopes, but nowhere in the Iowan drift region is there broken or hilly ground in the usual acceptation of the term. Along many of the streams the fields may be cultivated practically to the water's edge as is well illustrated in figures 12 and 13. 
While the soils developed on the Iowan drift agree in certain particulars, there are yet varieties depending on the slope of the surface and the composition of the subsoil. Whenever the drift attains any considerable thickness, the soil is a black loam, usually somewhat sandy, rich in humus and containing a high percentage of calcium carbonate. On the highlands in the northwestern part of Lime Creek township, the subsoil is a moderately tenaceous drift clay, but the slopes of the surface insure perfect drainage. On the level space between the highlands and the modern valley of Lime creek the underlying Buchanan gravels furnish under drainage of the most perfect character. A somewhat anamolous type of soil for a glaciated area occurs in the regions of thin drift already noted, where the drift materials are represented chiefly by bowlders, and decomposed shales of Lime Creek age are stirred by the tools and processes of agriculture. The spaces over which the soils are simply decomposed shales, are; however, very small, for even where the shales are disturbed by cultivation, there was originally enough of drift to contribute a very important element to the soil.

In that portion of the county occupied by the Altamont moraine, the surface is generally broken and hilly as shown in figure 16. The low ground is mostly wet and marshy in seasons of average rainfall, but the hills are dry and easily cultivated. The soil is a rich loam, not so deep as on some portions of the Iowan arêa, but richer in calcium carbonate, and even better adapted to the cultivation of cereals. In a relatively small area around the margin of Clear Lake the soils are sandy; and in the extinct ponds and lakes whose Basins have been filled or drained, a rich peaty soil, charged with shells of pond snails, is capable of supporting annually very heavy crops of grass.

There are no poor soils in the county. With the exception of the marshy spaces in the Altamont moraine, and a few low or otherwise unfavorably located spots in the region of the Iowan drift, every foot almost of the county can be 


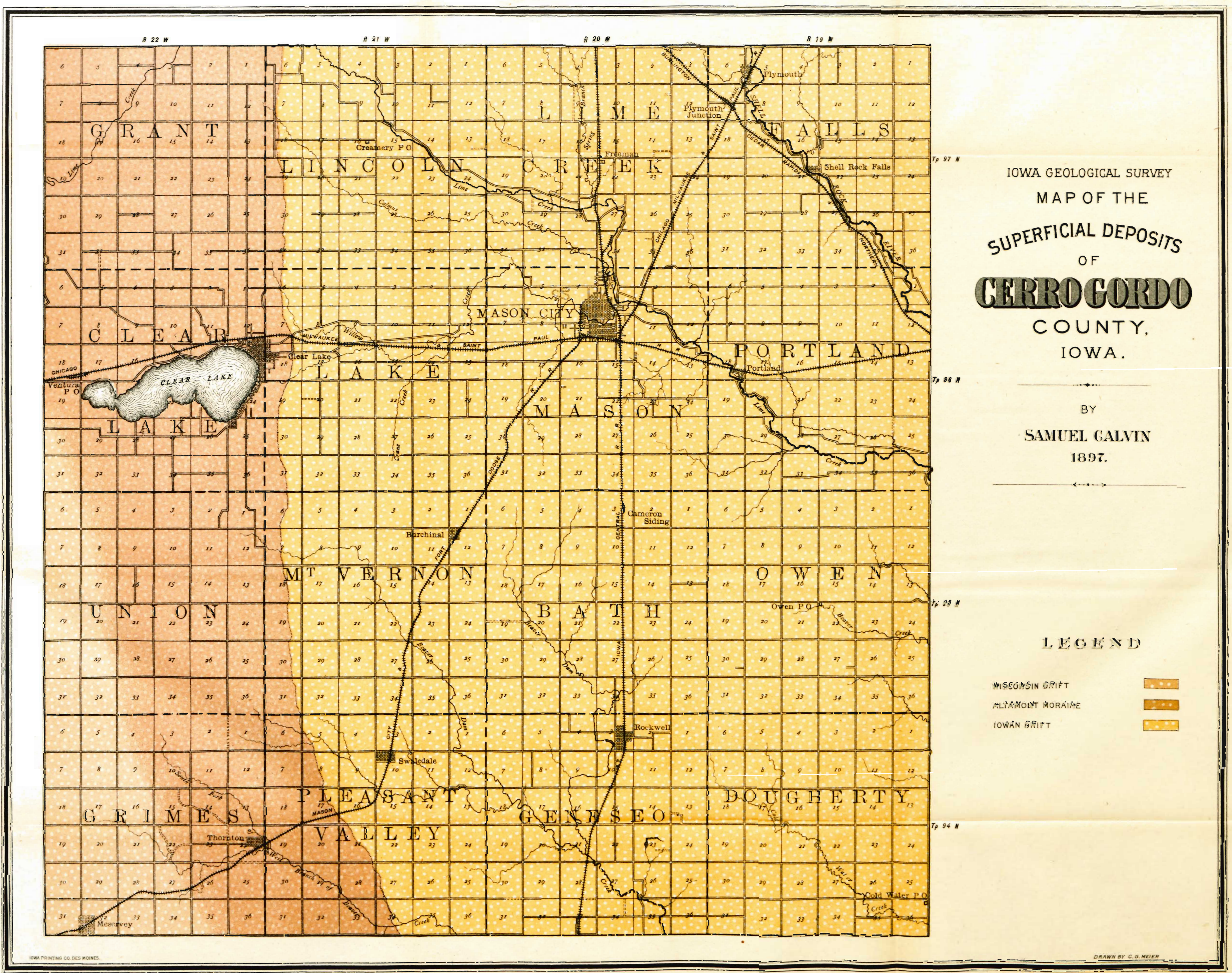


cultivated. While the calcareous drift soils are especially well adapted to the cultivation of cereals and grasses, it is still true that there are no annual crops suited to this climate that may not be attempted with reasonable hopes of success.

\section{Deformations.}

There are many small folds and varying dips in the Cedar Valley limestones and in the overlying Lime Creek shales, but in no case is there evidence of deformation affecting the crust to any considerable depth. The folding of the Cedar Valley limestones is most frequently observed along the Shell Rock river between Plymouth and Nora Springs. Some of the more striking cases were noted in connection with the description of the geological structure of that region. The folds in question are not parallel one to the other, and cannot be said to constitute a system. It is not certain that they are due to crushing or lateral pressure. In some cases at least, and probably in all, the apparent folds and local examples of dip have been caused by intercalation of lentils, or by rapid local thinning or thickening of certain beds, as is well shown in the Portland section on Lime creek, figure 20.

The Lime Creek shales at Hackberry Grove show some undulations, with a slight general dip to the southwest; while, three miles west of Hackberry, in section 31 of Portland township, the southwesterly dip, as previously noticed, exceeds fifty feet to the mile. This dip is continued for only a short distance, however, for the Owen beds that appear at the surface about one mile south of the last named locality, are exposed at a number of points in the southeastern quarter of the county, and the altitude of the several outcrops indicates that the general inclination of the strata is very slight.

\section{Unconformities.}

There are some indications of unconformity between the Lime Creek shales and the underlying limestones, although it must be admitted that the evidence is not altogether conclusive. 
For example, the limestones exposed along Limecreek, between Portland and Hackberry Grove, show no beds higher than No. 5 of the general section of the Cedar Valley stage (page 160), and the shales at Hackberry seem to rest on this member of the Cedar Valley section. Combining the exposures at Rockford and Nora Springs in Floyd county, there are forty-three feet of strata, Nos. 6 and 7, belonging to the Cedar Valley stage above No. 5 of the general section, and the Rockford exposures of the Lime Creek shales lie above No. 7. The strongest indications of unconformity are found at Mason City, and lie in the fact that the yellow and blue clays of Lime Creek age, worked by the Mason City Brick \& Tile Co, have a thickness of forty feet as demonstrated by borings. This brings the bottom of the deposit nearly on a level with the water in Willow creek about half a mile north of the works. Along Willow creek, however, at the nearest point, there are ledges of limestone, and the stromatoporoid reef No. 4, of the general Cedar Valley section, lies at the summit of the exposure. There is no very marked dip to the beds in this locality, and so the base of the shales must rest on, or very near to, the upper surface of the Stromatopora reef. Near Mason City Junction, less than three-fourths of a mile east of the brick and tile works, beds belonging to No. 5 of the Cedar Valley section are exposed at an altitude nearly on a level with the upper surface of the shales in the clay pit. Along the abandoned channel of Lime creek, north of Mason City, the equivalents of beds 5,6 and 7 of the general Cedar Valley section are developed above the stromatoporoid reef, and yet these beds all seem to be absent beneath the shales at the brick and tile works.

Two possibilities present themselves for consideration. First, the peculiar relations of the shales to the underlying limestones may indicate an emergence of the area, a period erosion, and subsequent subsidence between the Cedar Valley and Lime Creek stages, and so the phenomena may be due to true unconformity. Second, it is possible that there may have 
been rapid local thinning out of the later beds of the Cedar Valley limestones in a manner illustrated by some of the beds in figure 20 , and that there was no erosion interval between the two stages. The evidence at hand is not sufficient to warrant a statement as to which view is more probably correct.

The several Pleistocene deposits are unconformable on each other and on the underlying beds of sedimentary origin.

\section{ECONOMIC PRODUCTS.}

\section{Building Stones.}

Building stone is quarried at various points throughout the county. The principal quarries are in the Cedar Valley and Lime Creek stages of the Devonian. Some quarrying is also.

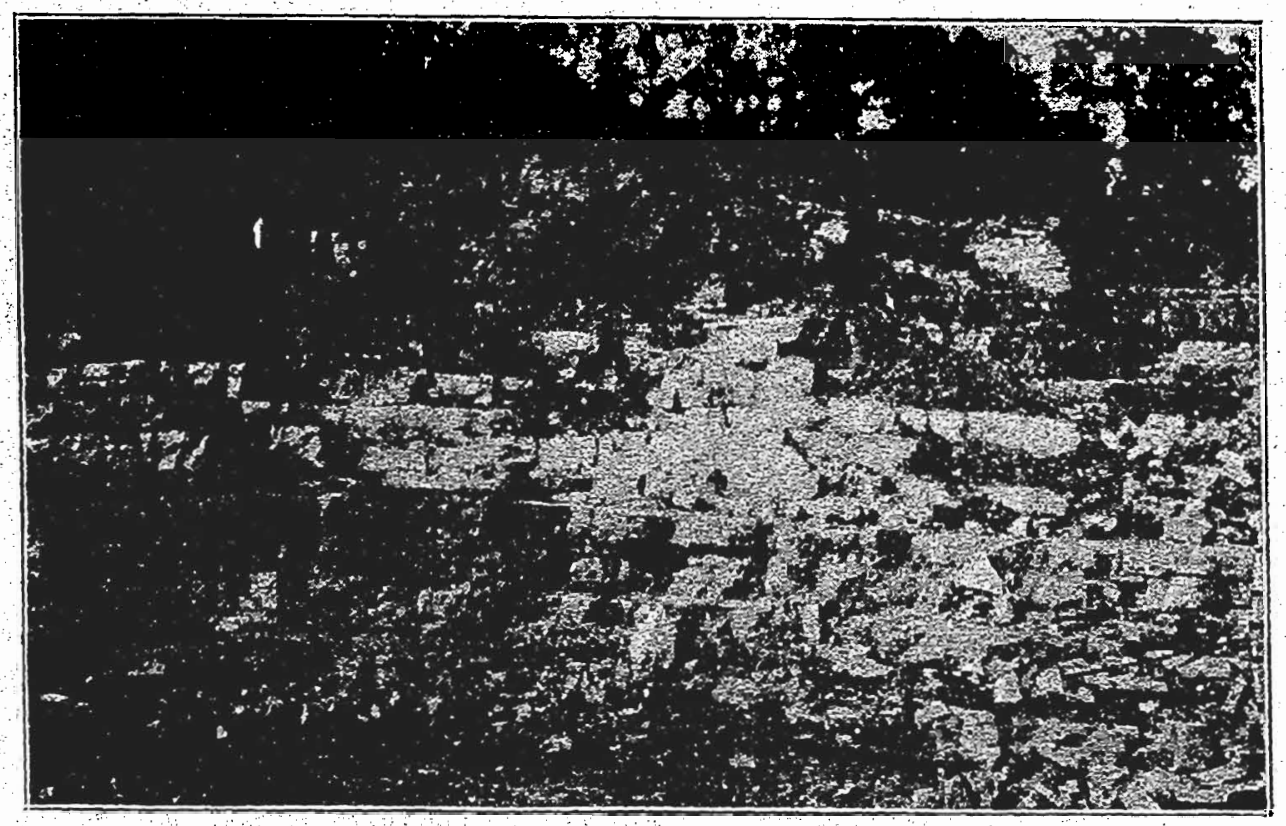

Fig. 22. Kúppinger quarry in northern part of Mason City, showing the regular beading below the stromatoporoid reef. In the rlew a man is standing at the level of the reef.

done in the Kinderhook beds of the Carboniferous, within a few rods of the county line in Franklin county, but none was observed in beds of this age in Cerro Gordo. The quarries of greatest value are located near Mason City, and all of these work the zones of whitish or grayish limestone and the granular dolomite, below the stromatoporoid reef. 
The Kuppinger quarry (Fig. 22) on the east side of Lime creek, in the northern part of Mason City, furnishes several hundred cords of good building stone annually. The section of this quarry has been already given. Beds 2 and 4 of the section are available for quarry purposes, but the stone from the dolomitic phase, No. 2, is much more desirable than that from the overlying limestones. The layers, as seen in Fig. 22, vary greatly in thickness and so afford a wide range of choice in this particular. The thicker layers furnish blocks suitable for heavy bridge piers, and the product of the thinner layers is adapted to lighter structures. A boiler and steam drill are the only labor-saving machines at present employed. The quarry is worked intermittently, and the market is local.

Belding Stone Co.-The quarries of the Belding Stone Co. are extensive openings in the bluffs facing Lime creek in the northwest quarter of section 27, Lime Creek township. No. 1 of the section of this quarry, page 150 , is made up of eight layers of granular dolomite varying in color through shades of brown, blue and gray. The first layer is 12 inehes thick and is used for rubble stone. Layers 2, 3, 7 and 8 are respectively $7,6,6$ and 8 inches in thickness and are taken out in blocks suitable for walls laid in definite courses. No. 4, which is 4 inches thick, is quarried for large slabs used in street crossings; and Nos. 5 and 6 , the first 13 , and the second 11 inches thick, furnish material for heavy walls. Above the "Blue cap," No. 2 of the section, there are dolomitic beds, the first of which furnishes stone for bridge piers or other heavy structures. The second and third are sufficiently fine in texture to be used for dimension stone, being cut for caps, sills, water tables and other purposes for which cut stone may be employed. The whitish fine-grained limestone above the dolomite, Nos. 4 and 5 of the section, is used for a variety of purposes. The quarry is equipped with a steam drill and a number of derricks. Much of the product of this quarry is shipped abroad; a wagon haul of half a mile, however, is at 
present necessary to reach a shipping point on the nearest railway, the Iowa Central.

Mason City Stone Co.-The Mason City Stone Co. has extensive quarries on the west side of Lime creek in the northwest quarter of section 34, Lime Creek township. The quality of the stone is in general the same as that at the quarries already described. The dolomitic phase has here a thickness of 19 feet, and the individual ledges vary from 4 to 22 inches in thickness. The dolomite is overlain by 12 feet of white or light grayish limestone. The quarry furnishes rubble, heavy footing stone, some dimension stone, stone for sidewalks or street crossings, and stone for range work. The stone for range work is easily shaped with the hammer. The quarries of this company have been worked for fifteen years. The Iowa Central railway has lately built a spur into the quarries, affording excellent facilities for loading and transportation. The product is marketed chiefly abroad, shipments being made for long distances north, south and west from Mason City, into territories that have no natural outerops of indurated rocks, or none that furnish stone suitable for building purposes.

Mason City Quarry Co.-On the opposite side of Lime creek, and a little north of the quarries last described, the Mason City Quarry Co. operates two or three small quarries. The beds quarried are the same as those already noted. Teams and wagons afford the only present means for transporting the product. The market is local, and the work in the quarries intermittent. There are derricks for handling the heavier blocks, but no other machinery apart from the ordinary hand drills and other tools in universal use in quarrying.

$\therefore$ OTHER QUARRIES IN CEDAR VALLEY LIMESTONE.

There are a number of small quarries worked at various points in the bluffs of Lime creek, Willow creek and Calmus creek. In the aggregate these produce annually a large 15 G. Rep. 
amount of stone. Among these may be mentioned the Peterson quarry in the southeast quarter of section 27, Lime Creek township; the quarries on Willow creek, on land of O. T. Denison, east of the crossing of the Iowa Central railway; the quarries on Calmus creek, in the northern part of Mason City; the quarry at Portland and others southeast of Portland, in Portland township, and a number of small quarries in the western part of Lime Creek and the eastern part of Lincoln townships. Mention must also be made of several quarries that afford excellent stone, in the bluffs of the abandoned channel of Lime creek in the northwest quarter of section 34 , Lime Creek township. There are also quarries near Shell. Rock Falls, and at points between Shell Rock Falls and Plymouth, in Falls township.

Quarries in the Owen beds-The Owen beds of the Lime Creek shales are quarried at the typical exposure in the southwest quarter of section 31, Portland township; in the southwest quarter of section 5 of Owen township; in section 12 of Dougherty, and in sections 3, 4, 10, 26 and 36 of Genesea. The stone from this horizon is usually a rather soft yellow earthy dolomite, and not of very high grade. Some portions of the quarries near Rockwell show firmer and more calcareous layers, and some exposures in section 35 of Geneseo township are composed of beds of moderately pure granular limestone. The stone from quarries of the Owen beds is much inferior to that from the Cedar Valley limestone near Mason City, and while these quarries are of very great local value, they are not likely to become commercially important.

Value of quarry products. - It is difficult to collect data respecting the annual value of the building stone produced in Cerro Gordo county. The year 1896 was one of unusual depression in the building stone industry, but the best information obtainable indicates that the value of the stone quarried in the county during this year does not fall very much short of $\$ 50,000$. In years of prosperity the demand was three times as great as during 1896. Were an equivalent 
value in gold, silver or coal produced, the importance of the geological products of the county would receive readier recognition.

Future of the stone industry. - The quarry industry of Cerro Gordo county is yet in its infancy. In the first place there are numerous vertical cliffs, as at Parker's mill (Fig. 19), that form natural quarry faces, and are so situated with respect to stripping and facilities for disposing of refuse, as practically to require no labor for their development. At all these exposures the admirable quality of the stone with respect to its power of resisting the weather, is well demonstrated. In the second place, Mason City is situated at the border of an enormous quarryless area whose supplies of building stone must all be imported. No situation could be better chosen for commanding the markets of the great plains stretching away for hundreds of miles to the northwest, west and southwest. Here is an area growing annually in wealth and population, but an area in which the indurated rocks are deeply buried under a thick mantle of drift. The facility with which stone may be quarried along Lime creek and its tributaries, coupled with the excellence of the product, should, therefore, enable Mason City to get an ever increasing share of the building stone trade in the vast stoneless empire to which this city is practically the gateway.

\section{Lime.}

The Cedar Valley stage is capable of furnishing indefinite supplies of lime-burning rock, some of which produces a very high grade of lime. At present; however, lime is made on a commercial scale at but one point in the county, namely, at the lime-kilns of A. T. Lein and brother, in Mason City. The limestone is obtained from a quarry nearly one-tenth of a mile in length, worked in the bluff overlooking Lime creek. The part worked exposes the following section. 
FEET.

4. Indefinitely stratified portion of the Stromatopora reef, with many laminar stromatoporoids ................. 3

3. Unstratified part of the reef with spheroidal stromato-

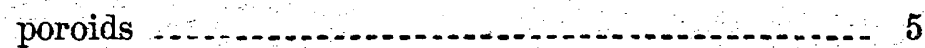

2. White or grayish, fine-grained limestone ............ 15

1. Granular dolomite ............ 4

Below No. 1, down to the level of the stream, there are ten or fifteen feet unexposed, but judging from neighboring outcrops the beds in this part of the bluff are probably dolomite resembling No. 1 in quality.

Tramways and small cars afford means for transporting the quarried rock to the kiln. The cars are carried to the top of the kiln, the kiln being charged from above. Coal is used for fuel, and the burning is completed in forty-eight hours after the process is fairly started. It is estimated that three tons of coal make 150 barrels of lime. The kiln is known as the Champion draw kiln and was designed by Lein Brothers. The amount of the product varies from year to year according to the demand, but the number of bushels made annually mounts up into the thousands. The value of the output adds a very important sum to the total value of the products manufac:tured from the geological resources of the county. A large amount of the lime made by A. T. Lein \& Brother is shipped to the quarryless region of deep drift west of Mason City. During the working season from six to eight men are constantly employed. The greater part of the lime manufactured at Mason City has been made from Nos. 2, 3 and 4 of the section at the limekiln. No. 2 especially produces a fine white lime that is held in much favor by many workmen for the reason, among others, that it slacks quickly and may be got ready for use in a short time. It is true, however, that lime made from the dolomitic phase, No. 1 , if properly treated will be found much superior to that from either No. 2,3 or 4 . It takes longer to slack the more highly magnesian lime, and it should lie in the mortar bed for a greater length of time, but the superior results will more than repay the additional 
trouble. For shipping purposes the lime from the dolomite has the great advantage of keeping for a long time without becoming air slacked, and if Mason City is to command the lime trade of the vast area that is hers by right of geographical position, attention should be given to the manufacture of lime from the dolomitized beds below No. 2. This lime will, without suffering deterioration, bear transportation for long distances, and may be kept in stock by dealers much longer than that from the purer limestone. Its property of setting harder, and its much greater power of resisting the chemical action of air and water which causes mortar to crumble and wash out of the joints in exposed portions of walls should commend the dolomitic lime at home as well as abroad.

\section{Clays.}

The blue and yellow, non-fossiliferous clays at the base of the Lime Creek shales are widely distributed in Cerro Gordo county and furnish inexhaustible amounts of material for use in the manufacture of clay goods of a great variety of kinds. For some purposes, as the manufacture of common structural brick, certain parts of the Iowa drift clays comparatively free from pebbles, will be found available. The drift clays of the Wisconsin stage contain so many limestone pebbles as to render them unfit for use in the manufacture of any clay products.

Mason City Brick and Tile Co.-At present clay goods are made at only one point in the county. The Mason City Brick and Tile Co. have an extensive plant (Fig. 23) in the southwestern part of Mason City. The clay used comes from the unfossiliferous portion of the Lime Creek formation. In the clay pit, which is just north of the factory, the beds exposed embrace twelve feet of blue shales overlain by twelve feet of yellow shales, with twelve to fifteen feet of blue shales known to exist below the bottom of the pit. The plant embraces the main factory building; steam heated drying sheds; an office building; six round, down-draft kilns; two 
up-draft kilns; a Sioux City Corliss engine of 125 horse power; two eighty horse power boilers; a Madden \& Co. machine with a capacity of 25,000 bricks daily; and the necessary hoists, tail

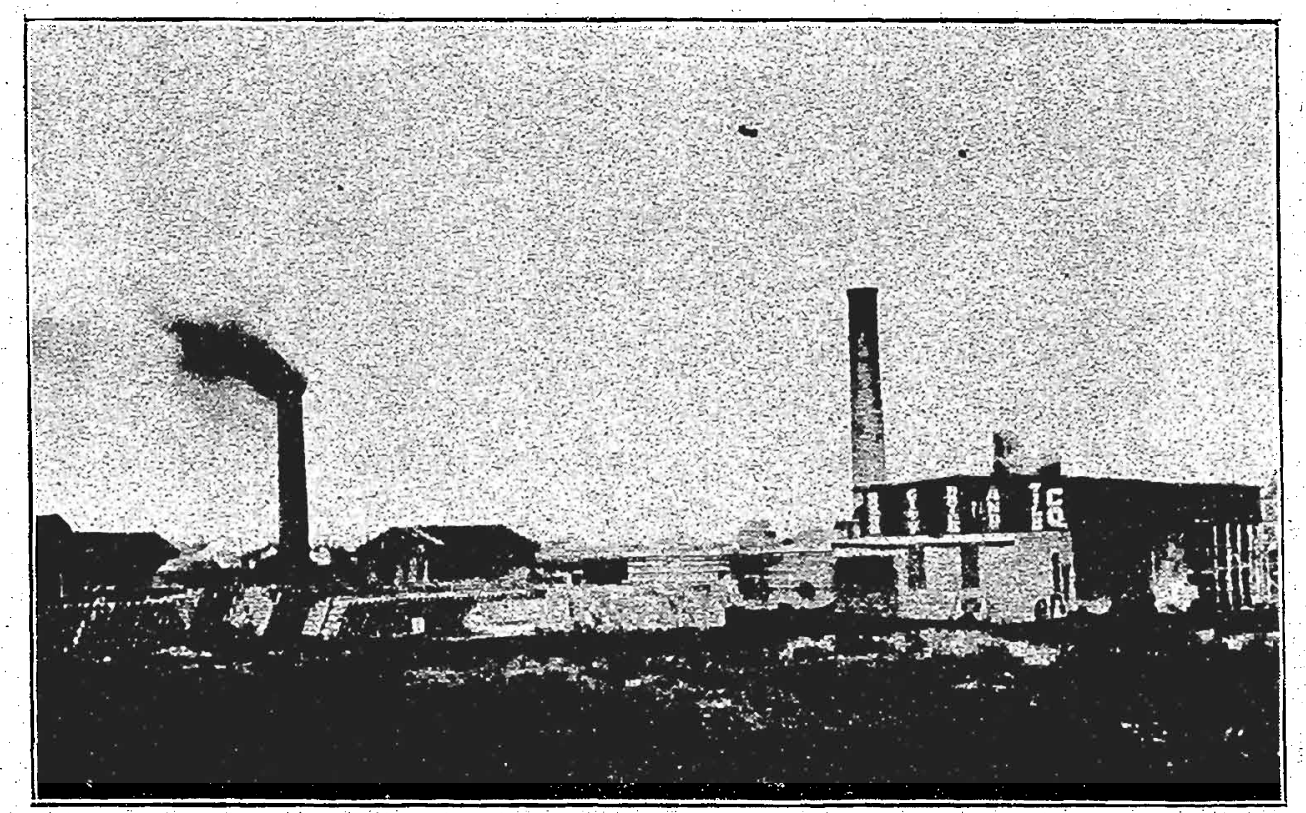

Fra. 23. Works of the Mason City Brick and Tile Co.

ropes, tramways, cars, pallets, etc., for handling the ware in the various stages of manufacture. The product of the factory includes.

1. End cut structural brick.

2. Hollow brick of the following dimensions:
(a) $8 \times 8 \times 12$ inches.
(b) $4 \times 8 \times 12$ inches.
(c) $4 \times 4 \times 12$ inches.
(d) $4 \times 8 \times 10$ inches.
(e) $4 \times 4 \times 10$ inches.
(f) $8 \times 8 \times 8$ inches.
(g) $4 \times 8 \times 8$ inches.
(h) $4 \times 4 \times 8$ inches.
(i) $4 \times 4 \times 4$ inches.
(k) $2 \frac{1}{4} \times 4 \times 8$ inches.

3. Agricultural drain tile three and one-half to twelve inches in diameter.

4. Sidewalk tile $2 \times 8 \times 8$ inches.

5. Window sills and caps. 
The clay burns to a light red color. The ware is very hard, ringing sharply under a gentle tap of the hammer, and is so compact as to be practically non-absorbent of water. Small crystals of selenite are diffused through the clay and cause a slight deposit of chalky looking powder on the surface of the ware in the process of the burning. For most of the product this in unobjectionable, but wherever it is desired to prevent its appearance, as in the case of face brick, it can be easily remedied by mixing a small amount of carbonate of baryta. with the raw clay. An analysis of the blue clay in the lower part of the pit was made by Prof. G. E. Patrick, with the following results.

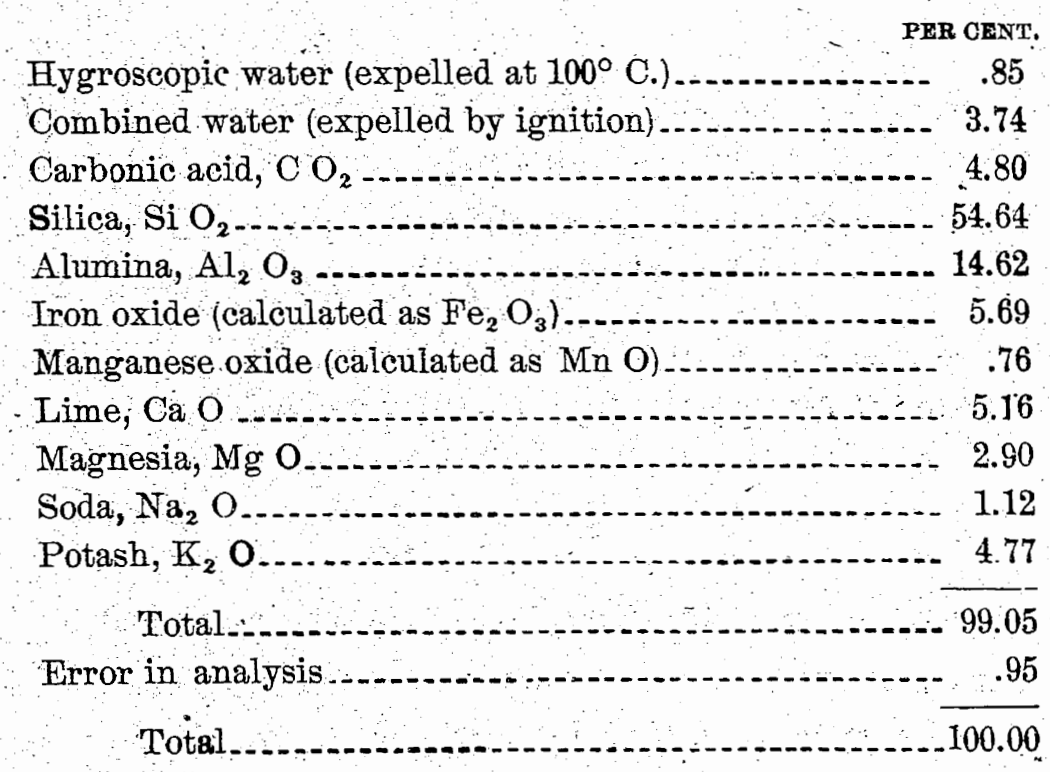

The factory of this company is operated continuously throughout the year; twenty-seven men are employed, and the value of the annual output exceeds $\$ 30,000$. The area in which the product of the factory finds a market has a radius of about 200 miles.

Nelson brickyard.-Some years ago a brick yard was operated about a mile north of Mason City. The clay used is a modified drift only about eight inches thick. This clay was tempered in the ordinary pug-mill, and the brick were made by hand. Temporary kilns were used for burning. No work has been done here, however, in recent years, and with 
abundant supplies of easily accessible clays in the Lime Creek shales, the drift clays of the county will not probably ever be in very great demand. It is from the beds of Devonian shales that the clay industries of the future, for this region, will get their suppiies of raw material.

Future of clay industries. - In respect to clays Mason City has the same advantages as in the matter of building stone and lime-burning rock. The raw material is of the best quality, and the supplies are inexhaustible. The facilities for shipping the manufactured products are good. An extensive region throughout which the demand must yearly increase, and yet without available deposits for manufacturing to supply its own needs, begins practically at the western limits of the city. And so industries based on the geological resources of the county-quarrying, lime-burning, and clay workingare certain, under wise and enterprising management, to grow in importance with the growth of the great territory that must either get supplies from Mason City, or from more distant points involving longer haulage and higher rates of freight.

\section{Peat.}

The extensive peat beds in the Altamont moraine are not now of very much value, owing to the cheapness of other forms of fuel, but in the future they may become of considerable importance. In some states the mucky material would be held in high esteem as a fertilizer, but the bountiful soils of Iowa will not need fertilizers of this kind for many years to come.

\section{Water Supplies.}

Cerro Gordo county is well supplied with springs and surface streams. The waters of the streams, in marked contrast with those in the southern and southwestern parts of the state, run clear the year round. Good, potable water may be obtained throughout most of the county, at moderate depths, in the sandy and gravelly beds of the Pleistocene 


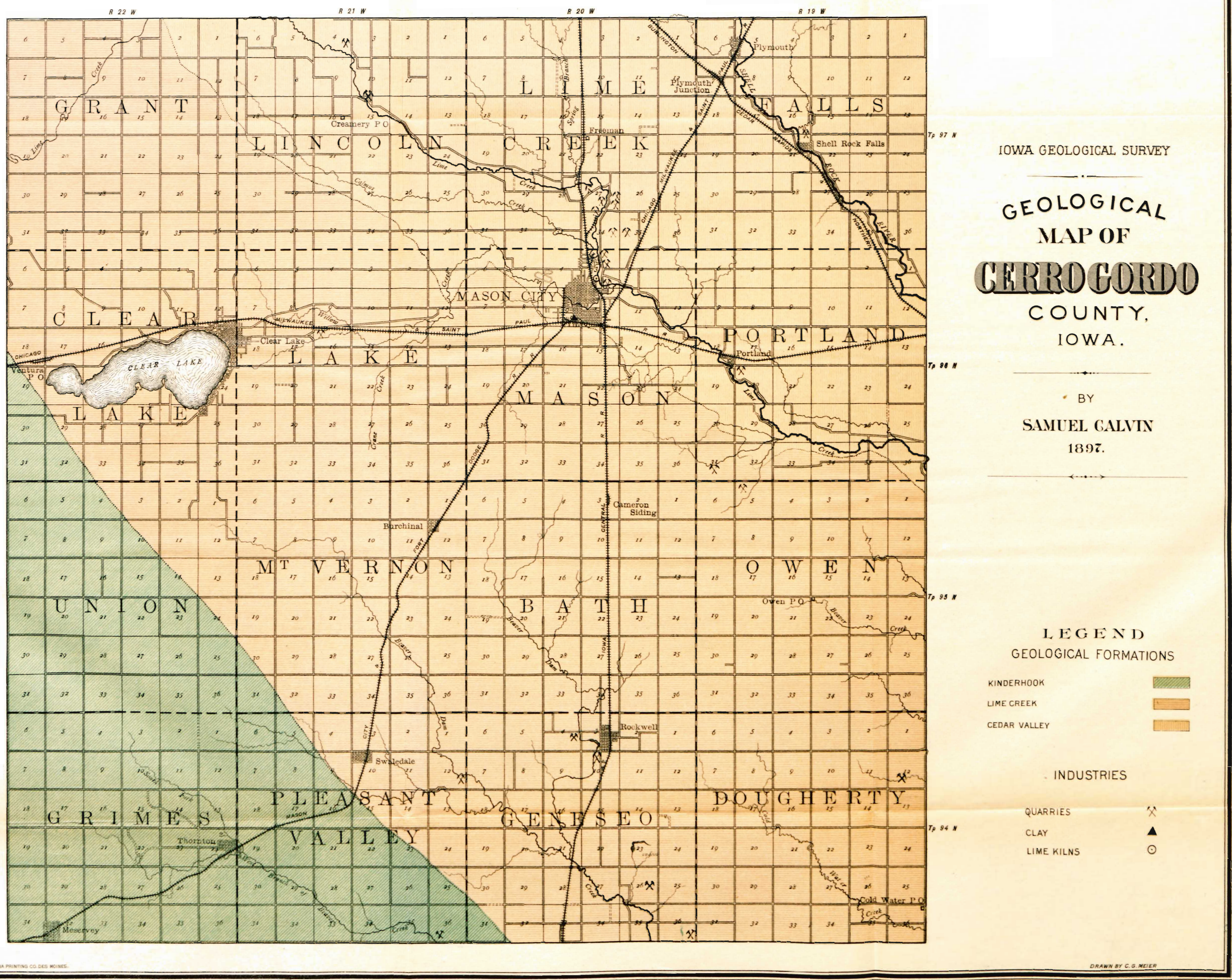


deposits. Most of the springs seem to have their origin in the porous beds of the Pleistocene, and flow takes place wherever these water-bearing beds, under proper conditions, come to the surface. Owing to the imperfect surface drainage of the morainic area in the western part of the county, the pebbly clays of Wisconsin drift are saturated with water, and abundant supplies are obtained from very shallow wells. Flowing wells frequently result from penetrating these clays to a moderate depth; and on the somewhat level plain into which the morainic knobs and ridges fade in the southwestern part of Grimes township, flowing wells are somewhat common. Clear Lake is probably fed almost exclusively by the underground streams of this morainic belt, and the underground supply is doubtless largely due to the fact that the surface drainage is as yet clogged, imperfect, undeveloped. Any causes that tend to facilitate the evaporation or the flow of water from the surface of the Wisconsin drift area and its marginal moraines, will diminish the volume of water in the lakes of the north-central part of the state.

MASON CITY DEEP WELL.

Water is found at varying depths in the indurated rocks below the Pleistocene beds. The most important supply from this source at present is that from the deep well at Mason City. The section of this well, copied from Norton's report; is as follows.

\begin{tabular}{|c|c|c|c|}
\hline 12. & Humus and drift $\quad \begin{array}{c}\text { THICK- } \\
\text { NEBS. }\end{array}$ & $\begin{array}{c}\text { DEPTH. } \\
28\end{array}$ & $\begin{array}{l}\text { ELEVA- } \\
\text { TION A. T. } \\
1,100\end{array}$ \\
\hline 11. & Devonian and Silurian ........ 276 & 304 & 824 \\
\hline 10. & Maquoketa__._. & 361 & 767 \\
\hline 9 ; & Galena-Trenton_........ & 766 & 362 \\
\hline 8. & Saint Peter & 871 & 257 \\
\hline 7. & Upper Oneota................ & 984 & 144 \\
\hline 6 . & New Richmond ................ & 1,034 & 94 \\
\hline 5. & Lower Oneota & 1,179 & -51 \\
\hline 4. & Saint Croix (Jordan) & 1,249 & -121 \\
\hline 3. & Saint Croix (Saint Lawrence) -174 & 1,423 & -295 \\
\hline 2. & Saint Croix (Basal sandstone) _ 45 & 1,468 & -340 \\
\hline 1. & Algonkian (?) penetrated.....-- & 1,473 & -245 \\
\hline
\end{tabular}

* Iowa Geol. Surv., vol. VI, p. 195. Des Moines, 1897. 
The main water supply in this well comes from Nos. 2-4, which collectively represent the Saint Croix sandstone. This sandstone is the source of the water in nearly all the deep wells of Iowa. No. 8 of the well section is very properly identified by Norton with the Saint Peter sandstone. This second sandstone marks one of the most persistent and most easily recognized of the geological horizons, and it extends with uniform characteristics underneath a large portion of the

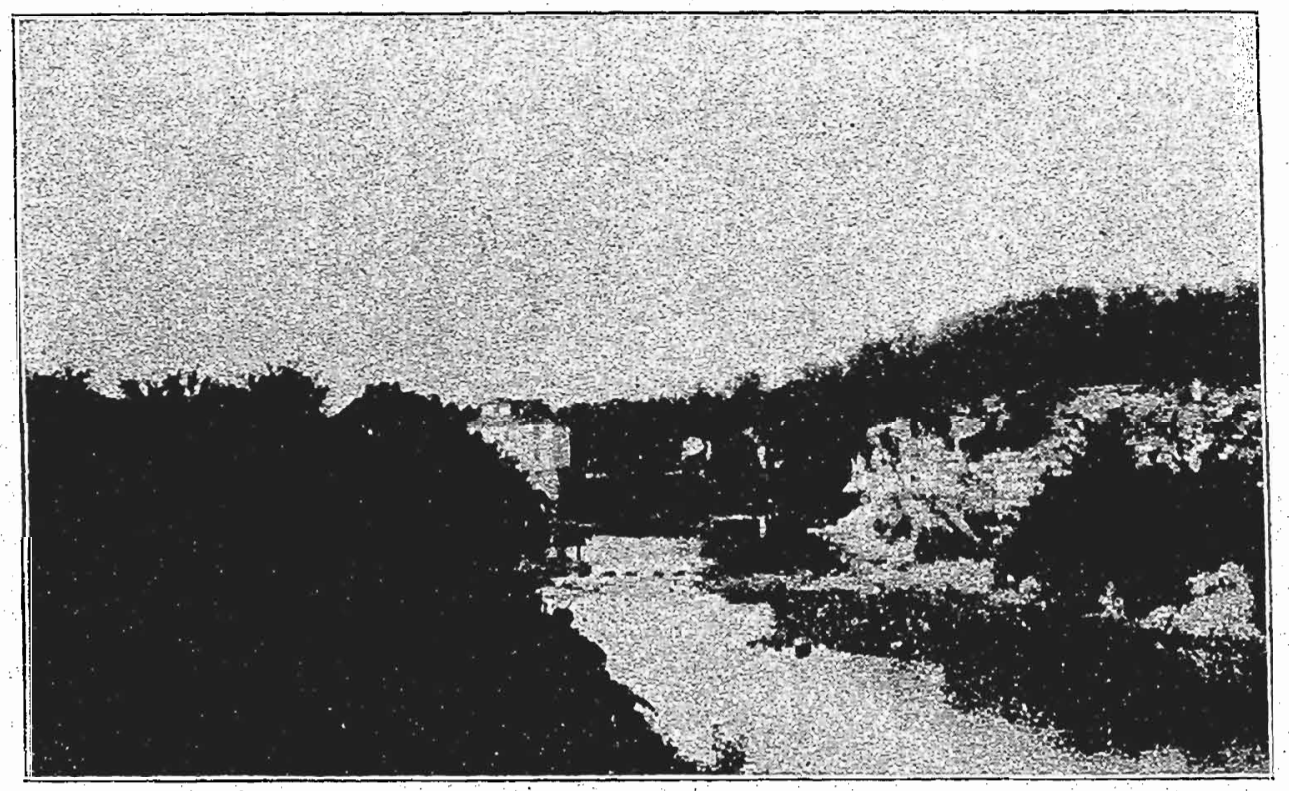

FIG. 24. Kuppinger's mill in the north part of Mason Ćity-a typlcal mlly site on Lime creek

state. The water in the Mason City well is excellent in quality, and the supply is ample for the present needs of the city.

\section{Water Powers.}

Out of a great many possibilities afforded by the streams of the county, water powers have been improved and utilized at only a few points. On Lime creek the Lincoln mills, in section 15 of Lincoln township, have a head of eight feet; the Kuppinger mill (Fig. 24), in the northern part of Mason City, has about the same head, and the Portland mill, at Portland, has also a fall of eight feet. The old Parker's mill at Mason City is located on Willow creek. On the Shell Rock river 
there are mills at Plymouth, and there is now an unused, but formerly well developed water power at Shell Rock Falls.

\section{ACKNOWLEDGMENTS.}

This report would be incomplete if it did not acknowledge the indebtedness of the author to the many interested friends of the Survey, who courteously aided in many ways the collection of the data on which the report is based. All information that could possibly be of service was cheerfully given, and some gave time and labor in the furtherance of the objects for which the Survey was conducted. Especial acknowledgments are due to O. T. Denison, superintendent of the Mason City Brick and Tile Co. Mr. Denison's thorough acquaintance with the county, coupled with the habit of close and accurate observation, made it possible for him to give such information and render such assistance as greatly reduced the time required to find and visit the points of most importance. Acknowledgments are also due to E. P. De Graw, of Lincoln Mills, and to Ade Randall, S. C. Belding, A. T. Lein and others interested in the stone and lime industries of the county. Valuable assistance in the field work was received from Frederick Larrabee, Harold M. McLaughlin and Hugh H. Shepard, and in a part of the work done on Pleistocene geology the assistance of Dr. S. W. Beyer was a highly appreciated advantage. To these, and to the many others not specifically mentioned the author extends sincere thanks. 
